\section{OAK RIDGE NATIONAL LABORATORY}

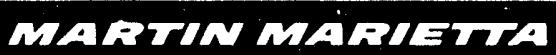

\author{
NAVY \\ MOBILITY FUELS \\ FORECASTING SYSTEM \\ REPORT:
}

\section{WORLD PETROLEUM TRADE FORECAST FOR THE YEAR 2000}

S. DAS 
This report has been reproduced directly from the best available copy.

Available to DOE and DOE contractors from the Office of Scientific and Technical Information, P.O. Box 62, Oak Ridge, TN 37831; prices available from (615) 576-8401, FTS 626-8401.

Available to the public from the National Technical Information Service, U.S. Depertment of Commerce, 5285 Port Royal Rd., Springfield, VA 22161.

This report was prepared as an account of work sponsored by an agency of the United States Government. Neither the United States Government nor any agency thereof, nor any of their employees, makes any warranty, express or implied, or assumes any legal liability or responsibility for the accuracy, completeness, or usefulness of any information, apparatus, product, or process disclosed, or represents that its use would not infringe privately owned rights. Reference herein to any specific commercial product, process, or service by trade name, trademark, manufacturer, or otherwise, does not necessarily constitute or imply its endorsement, recommendation, or favoring by the United States Government or any agency thereof. The views and opinions of authors expressed herein do not necessarily state or reflect those of the United States Government or any agency thereof. 
Energy Division

\title{
NAVY MOBILITY FUELS FORECASTING SYSTEM REPORT: WORLD PETROLEUM TRADE FORECASTS FOR THE YEAR 2000
}

\author{
Principal Investigator \\ S. Das \\ ORNL Program Manager \\ R. M. Davis
}

Date Published - December 1991

\author{
Report Prepared for \\ Navy Energy \& Natural Resources Office \\ Office of Naval Research \\ Department of the Navy
}

Navy Program Manager

A. Roberts

Prepared by the Oak Ridge National Laboratory

Oak Ridge, Tennessee 37831 managed by MARTIN MARIETTA ENERGY SYSTEMS, INC. for the U.S. DEPARTMENT OF ENERGY under contract DE-AC05-84OR21400 
LIST OF TABLES $\ldots \ldots \ldots \ldots \ldots \ldots \ldots \ldots \ldots \ldots \ldots \ldots \ldots \ldots \ldots \ldots \ldots \ldots \ldots$

LIST OF FIGURES $\ldots \ldots \ldots \ldots \ldots \ldots \ldots \ldots \ldots \ldots \ldots \ldots \ldots \ldots \ldots$

ACRONYMS AND ABBREVIATIONS $\ldots \ldots \ldots \ldots \ldots \ldots \ldots \ldots \ldots \ldots \ldots \ldots$ vii

ACKNOWLEDGEMENTS $\ldots \ldots \ldots \ldots \ldots \ldots \ldots \ldots \ldots \ldots \ldots \ldots \ldots \ldots \ldots$

ABSTRACT $\ldots \ldots \ldots \ldots \ldots \ldots \ldots \ldots \ldots \ldots \ldots \ldots \ldots \ldots \ldots \ldots \ldots \ldots \ldots \ldots \ldots$

EXECUTIVE SUMMARY $\ldots \ldots \ldots \ldots \ldots \ldots \ldots \ldots \ldots \ldots \ldots \ldots \ldots \ldots \ldots \ldots \ldots \ldots$

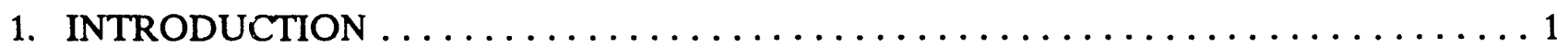

2. THE NAVY MOBILITY FUELS FORECASTING SYSTEM (NMFFS) FOR PETROLEUM MARKET FORECASTS $\ldots \ldots \ldots \ldots \ldots \ldots \ldots \ldots \ldots \ldots \ldots \ldots$

3. SCENARIO DESCRIPTION $\ldots \ldots \ldots \ldots \ldots \ldots \ldots \ldots \ldots \ldots \ldots \ldots \ldots \ldots \ldots$

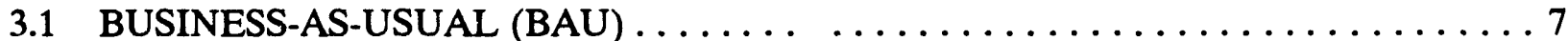

3.2 BAU SENSITTVITY ANALYSES $\ldots \ldots \ldots \ldots \ldots \ldots \ldots \ldots \ldots \ldots \ldots \ldots$

3.3 LOW U.S.S.R. CRUDE OIL PRODUCTION (LOIL) $\ldots \ldots \ldots \ldots \ldots \ldots \ldots \ldots$

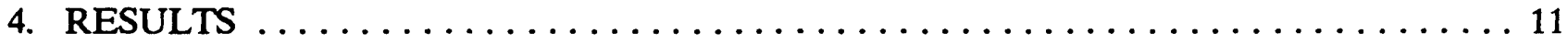

4.1 WORLD OIL SUPPLY AND DEMAND $\ldots \ldots \ldots \ldots \ldots \ldots \ldots \ldots \ldots \ldots \ldots \ldots \ldots$

4.2 U.S. PETROLEUM SUPPLIES $\ldots \ldots \ldots \ldots \ldots \ldots \ldots \ldots \ldots \ldots \ldots \ldots \ldots \ldots \ldots$

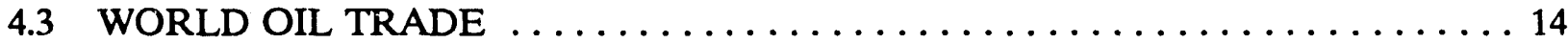

4.4 WORLD REFINERY OUTPUT $\ldots \ldots \ldots \ldots \ldots \ldots \ldots \ldots \ldots \ldots \ldots \ldots \ldots \ldots$

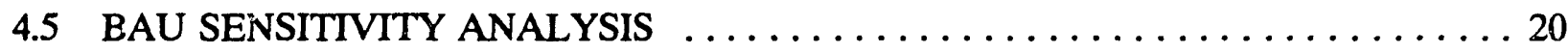

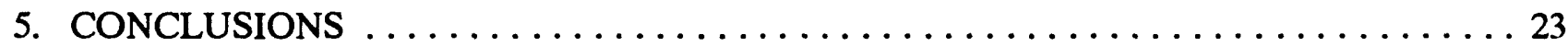

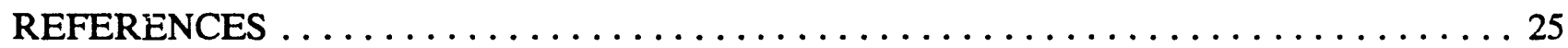

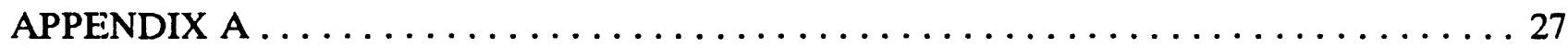

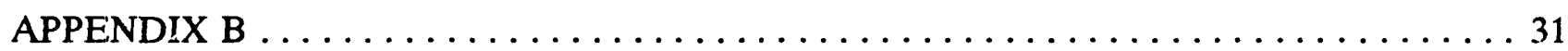

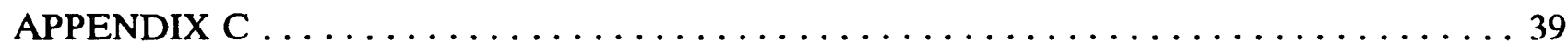


Table 4.1. U.S. petroleum supply (million barrels per day) $\ldots \ldots \ldots \ldots \ldots \ldots \ldots \ldots$

Table 4.2. Worldwide petroleum supply (million barrels per day) $\ldots \ldots \ldots \ldots \ldots \ldots \ldots$

Table 4.3. World output of refined petroleum product (million barrels per day) $\ldots \ldots \ldots 19$

Table 4.4. BAU scenario sensitivity analyses results $\ldots \ldots \ldots \ldots \ldots \ldots \ldots \ldots \ldots \ldots \ldots$

\section{LIST OF FIGURES}

Figure 4.1. Worldwide petroleum supply and demand in 1989 and $2000 \ldots \ldots \ldots \ldots$

Figure 4.2. World petroleum trade forecasts for year 2000 "BAU" scenario . . . . . . 15

Figure 4.3. World petroleum trade forecasts for year 2000 "LOIL" scenario . . . . . . . . 16 


\section{ACRONYMS AND ABBREVIATIONS}

\begin{tabular}{|c|c|}
\hline ANWR & Arctic National Wildlife Refuge \\
\hline BAU & business as usual \\
\hline Comecon & Council for Mutual Economic Assistance \\
\hline DOD & U.S. Department of Defense \\
\hline DOE & U.S. Department of Energy \\
\hline DON & U.S. Department of the Navy \\
\hline EIA & Energy Information Administration \\
\hline GDP & Gross Domestic Product \\
\hline LOIL & Low U.S.S.R. Crude Oil Production \\
\hline MBD & thousand barrels per day \\
\hline MMBD & million barrels per day \\
\hline NATO & North Atlantic Treaty Organization \\
\hline NMFFS & Navy Mobility Fuels Forecasting System \\
\hline OECD & Organization for Economic Cooperation and Development \\
\hline OTM & Oil Trade Model \\
\hline OPEC & Organization of Petroleum Exporting Countries \\
\hline ORNL & Oak Ridge National Laboratory \\
\hline OCS & Outer Continental Shelf \\
\hline PAL & Petroleum Allocation Model \\
\hline RYM & Refinery Yield Model \\
\hline
\end{tabular}




\section{ACKNOWLEDGEMENTS}

Throughout the development and application of the Navy Mobility Fuels Forecasting System, technical guidance and collaboration have been received from the Navy Energy and Natural Resources Office, the Naval Air Propulsion Center, and the David Taylor Naval Ship Research and Development Center. The staff of the Energy Information Administration, Department of Energy, have furnished technical support, data resources and access to the principal models used in the analysis. Russ Lee and Jerry Hadder of ORNL provided many insights and technical guidance, without which this report could not have been completed successfully. The report benefitted greatly from comments on earlier drafts that were provided by Dick Davis, Jerry Hadder, and Russ Lee of ORNL; and particularly by Buck Nowack of the Naval Air Propulsion Center. Pam Witcher did a masterful job on editing the manuscript. The valuable contributions of these individuals and organizations are gratefully acknowledged. 


\begin{abstract}
The Middle East will continue to play the dominant role of a petroleum supplier in the world oil market in the year 2000, according to business-as-usual forecasts published by the U.S. Department of Energy. However, interesting trade patterns will emerge as a result of the democratization in the Soviet Union and Eastern Europe. U.S. petroleum imports will increase from $46 \%$ in 1989 to $49 \%$ in 2000 . A significantly higher level of U.S. petroleum imports (principally products) will be coming from Japan, the Soviet Union, and Eastern Europe. Several regions, the Far East, Japan, Latin America, and Africa will import more petroleum. Much uncertainty remains about the level of future Soviet crude oil production. U.S.S.R. net petroleum exports will decrease; however, the United States and Canada will receive some of their imports from the Soviet Union due to changes in the world trade patterns. The Soviet Union can avoid becoming a net petroleum importer as long as it (1) maintains enough crude oil production to meet its own consumption and (2) maintains its existing refining capacities. Eastern Europe will import approximately $50 \%$ of its crude oil from the Middle East.
\end{abstract}




\section{EXECUTIVE SUMMARY}

This report considers the Soviet Union, Eastern Europe, and China as free market economies in making business-as-usual world petroleum trade forecasts for the year 2000 . Forecasts are based primarily on two scenarios considered here in detail using world wide petroleum supply and demand projections made by the U.S. Energy Information Administration (EIA). The difference between the two scenarios (i.e., business as usual (BAU) and low U.S.S.R. crude oil prcduction (LOIL)) lies in (1) estimates of the U.S.S.R. crude oil production level [7.9 million barrels per day (MMBD) in case of the LOIL scenario as compared to 10.5 MMBD under the BAU scenario] and (2) crude oil production in the Middle East, Latin America, Africa, and the Far East are allowed to be higher than the BAU level to compensate for the Soviet crude oil production loss. In addition, several sensitivity analyses to the BAU scenario were used to assess the variability and stability of the key model's projections of the BAU scenario in response to different assumptions about the energy prospects of the Soviet Union and Eastern Europe. The EIA's Oil Trade Model (OTM) was used to make the forecasts. The EIA version was augmented with Oak Ridge National Laboratory (ORNL) data for the Soviet Union and Eastern Europe; and China was added to the existing nine other countries represented within the region of the Far East.

Results indicate that (1) the Middle East will continue to be the dominant oil supplier, especially with uncertainty in the availability of supply from the Soviet Union, and (2) interesting world trade patterns will ensue. Under the BAU scenario, the Middle East crude oil production is forecast to be $35.5 \%$ higher than the 1989 level and an additional $5.3 \%$ will be available due to the Soviet crude oil production loss under the LOIL scenario.

Under the BAU scenario, crude oil production is forecasted to decline (from 12.1 MMBD in 1989 to 10.5 MMBD in 2000) in the Soviet Union as inefficiencies and lack of investments will continue to plague its oil industry. Current trends toward lower crude oil prices will not encourage higher levels of crude oil production in the year 2000 from the major oil producing regions of the Far East. If U.S. domestic crude oil production is maintained at its current level, its higher consumption in 2000 will be met by an increase in petroleum imports from $46 \%$ in 1989 to $49 \%$ in 2000 . A significantly higher level of U.S. petroleum imports (particularly refined products such as gasoline and naphthas) will be coming from Japan, and the Soviet Union. Under the LOIL scenario, increased crude oil supplies from Latin America, Africa, and the Far East going mainly to satisfy their own demand will allow 1.0 MMBD of Soviet refined product exports to be exported to the U.S.

Not much change is forecasted for Canada under the BAU scenario except for its receiving some (i.e., $0.8 \mathrm{MMBD}$ ) of the Soviet Union's redirected crude oil and refined products exports. The crude oil production increase in Western Europe (mainly from the North Sea) will help to reduce its net imports. Western Europe's exports to the Soviet 'Jnion will increase as the U.S.S.R.'s crude oil production declines from 10.5 MMBD to a level of 7.9 MMBD under the LOIL scenario.

Under the BAU scenario, Japan and the Far East will continue to meet their demand with increased imports, with a major portion coming from the Middle East. Increases in crude oil production in Latin America and Africa will not be great, thereby causing a decline in net petroleum exports from these regions enough to meet their growth in domestic demand. A significant increase in refined product imports is forecast for Latin America. However, under the LOIL scenario, 
increase in crude oil production in Latin America, Africa, and the Far East will cause a decline in imports in these regions.

A decline in the U.S.S.R.'s crude oil production forecast under the BAU scenario will cause a reduction of $23 \%$ in its net petroleum exports as compared to the 1989 level. Some U.S.S.R. crude oil will be exported to U.S. ard Canada instead of all exports going to Eastern Europe. More Soviet crude oil than refined products will be coming to the U.S.; the reverse will be true in case of Canada. There will be no net Soviet petroleum exports when its crude oil production is forecast to decline further from the BAU scenario level under the LOIL scenario. As long as the Soviet Union can maintain enough crude oil production to meet its own consumption and its existing refining capacities, it can avoid becoming a net petroleum importer. However, current conditions suggest otherwise. Hard currencies may not be available to curb further deterioration of existing crude oil production and refinery capacities.

Eastern Europe will import approximately $50 \%$ of its crude oil from the Middle East under the BAU scenario; 100\% under the LOIL scenario. An increase in Eastern Europe refinery activities will help to increase its export of refined products, some of which will be coming to the United States.

For the Navy, vulnerability to disruptions in the Middle East petroleum supply will continue to be an issue of concern amidst uncertain future supplies from the Soviet Union. However, some of the Soviet Union's redirected petroleum supplies coming to the U.S. may help to reduce the Navy's dependency on supplies from the Middle East. 


\section{INTRODUCTION}

Within the last few years, several significant events have occurred in the world oil market, the effects of which may be substantial in the coming years. The most notable events are the democratization of the Soviet Union and Eastern Europe and the Iraqi invasion of Kuwait. The market reaction witnessed during the latter event made forecasters reassess their thinking about changes in the world oil market reaction mechanisms (Verleger, Jr. 1990). The quality as well as the quanity of the replacement crude oil for embargoed crude oil from Iraq and Kuwait became an important issue. The replacement crude oil was heavier and thus the barrel-for-barrel replacement of the embargoed crude oil did not solve the crude oil quality problem.

Numerous studies have examined in detail the issue of the vulnerability of crude oil supply from the Persian Gulf region, which encompasses almost two-thirds of the world's oil reserves (Cutler 1986; Buck et al. 1973; Das et al. 1988; Das et al. 1990; Lee. Das, and Leiby 1991; Hadder et al. 1987; EIA 1989). However, the dynamics of energy supply and demand within the Soviet Union, Eastern Europe, and China have largely been ignored in these prior studies for reasons of political isolationism. In those studies, considerations were given entirely to the free market economies, in which the U.S.S.R.'s, Eastern Europe's, and China's contributions were relatively insignificant to the global net export or import balance. This simplistic treatment of one-third of global energy consumption and the world's energy reserves (e.g., approximately $9 \%, 40 \%$, and $47 \%$ of total world crude oil, natural gas and recoverable coal reserves, respectively (EIA 1991a)) sufficed until the current introduction of political reforms in the Soviet Union and Eastern Europe. Presuming that energy isolationism will definitely be unrealistic for the future, the focus of this worldwide petroleum trade analysis for the year $\mathbf{2 0 0 0}$ is to take into account the supply art demand of the Soviet Union, Eastern Europe, and China.

These countries face numerous challenges with the onset of democratization. U.S.S.R. oil production accounts for $22 \%$ of world output, and its energy exports account for about $40 \%$ of Soviet hard currency earnings (of that 30\% comes from oil) (International Monetary Fund et al. 1990). However, the energy industries accounting for nearly half of industrial investment are currently in a precarious position. Last year's $6 \%$ decline in the Soviet crude oil production and its halt to imports of barter crude oil from Iraq following Saddam Hussein's invasion of Kuwait contributed to a sharp reduction in its availability of oil for export ${ }^{1}$. Crude oil production fell from 12.5 million barrels per day (MMBD) in 1987 and 1988 to an estimated 11.4 MMBD in 1989; it was even lower last year (approximately 10.5 MMBD). It is difficult to be optimistic about any immediate revival in the Soviet Union's economic fortunes. Oil deposits in western Siberia that were once sizeable and relatively easy to exploit are declining (Petroleum Economist 1991). New developments center on smaller, deeper finds in remote areas that are environmentally hostile such as Soviet Central Asia, northern and eastern Siberia, and Sakhalin. These areas are devoid of infrastructure and in need of better sophisticated technology and enormous investments. Production and energy usage inefficiencies abound.

\footnotetext{
${ }^{1}$ The U.S.S.R imports mainly crude oil, all coming from the Middle East. More than $80 \%$ of total 0.3 MMBD Soviet crude oil imports in 1989 came from Iraq. Crude oil imports help the Soviet Union to maintain a higher level of crude oil and refined product exports of around 3.5 MMBD.
} 
Soviet energy planners are exerting increased pressure on the use of gas, coal, and nuclear power to free up oil for export. Transport shortages and public opposition to more use of nuclear power are making fuel switching difficult. A lack of flexibility exists today in the Soviet energy sector because of insufficient oil and gas storage capacity to cope with marked changes in demand, refinery shutdowns, mismatch between the refinery capacity and the structure of demand (Sagers and Green 1986), and pipeline bottlenecks. Unrest throughout Soviet populations is adding to these physical problems, making it increasingly difficult to guarantee supplies of manpower and equipment to oilfields and the transport of fuel across the Soviet Union.

The Soviet government has made a commitment to implement a range of extraordinary measures to reverse the drop in oil production, but the process has been slow. Reform plans have been proposed to lease fuel deposits to foreign oil companies; foreign investment is a must to revive the Soviet oil industry. To attract foreign investments, much remains to be done in the areas of political and economic stability, legal and regulatory concerns of potential investors, ownership of energy resources, and clearly defined environmental standards.

Eastern Europe faces challenges as the Soviet Union decides to discontinue intra-Comecon ${ }^{2}$ trade arrangements and to carry out oil trade in convertible currency (i.e., dollars) at world prices. The domestic economic implications would be far-reaching in these regions. In the past, Soviet exports accounted for $75 \%$ of Eastern Europe's total oil consumption. Eastern European countries were able to base their economic growth on Soviet supplies of fossil fuels and heavy reliance on domestic energy production, primarily of coal but also of nuclear power. Extraction of coal resources has appeared to reach its limit, requiring ever higher inputs of capital with no guarantee of higher production. Coal exporting faces increased competition in western markets.

The effects of democratization on China's oil industry remain to be seen. Crude oil production in China is considerably higher than in Eastern Europe. However, on the basis of energy consumption per unit of Gross Domestic Product (GDP), the Chinese economy is the most energy intensive in the world. The outlook for the Chinese oil industry may not be good because of its current return to reliance on central control to solve the problems generated by the partial reforms of the last few years. Onshore crude oil production is declining. Rising imports of crude oil and products raise the question of how and where to access petroleum supply. The domestic refining system is unlikely to expand rapidly enough to keep up with the growth in demand. Legal and economic reforms are necessary to promote joint ventures with the West that could help the refining industry.

At present only speculation prevails for the future oil situation for the Soviet Union, Eastern Europe, and China. Crude oil production will be dictated to a large extent by the availability of hard currency for necessary investments in the industry. Consumption will depend on the effectiveness of conservation measures, transition towards less energy intensive light industry, and fuel switching (particularly in the Soviet Union). These supply and demand uncertainties are reflected in current literature (Ashby and Dreyfus 1990; Fridley 1990; Gaffney, Cline \& Associates 1989; Korchemkin 1989; and EIA 1990a).

\footnotetext{
${ }^{2}$ The Council for Mutual Economic Assistance (Comecon) members were Bulgaria, Czechoslovakia, East Germany, Hungary, Poland, Romania, Mongolia, Cuba, the Soviet Union, and Vietnam. The organization was disbanded in June 1991.
} 
This paper attempts to forecast worldwide petroleum trade in the year 2000 by taking into account the supply and demand of the Soviet Union, Eastern Europe, and China. Two scenarios are considered here: (1) business as usual (BAU) and (2) low U.S.S.R. crude oil production (LOIL). Supply ar.d demand uncertainties in the Soviet Union, Eastern Europe, and China are considered in the sensitivity analyses of the year 2000 BAU scenario. The following section discusses the modeling system used for the analysis, and a detailed description of the two scenarios and sensitivity analyses is provided in Sect. 3. Detailed results of the two scenarios are discussed in Sect. 4. The same section also includes the highlights of the results of the sensitivity analyses of the BAU scenario. The final section draws major conclusions about the worldwide petroleum trade forecasts for the year 2000. 


\section{THE NAVY MOBILITY FUELS FORECASTING SYSTEM (NMFFS) FOR PETROLEUM MARKET FORECASTS}

The NMFFS is based on a simplified representation of the world oil market. The forecasting system consists of the Oil Trade Model (OTM) and the Refinery Yield Model (RYM). OTM (DACVA 1989) is used to forecast detailed regional crude oil and refined product distribution. The OTM is similar to the Petroleum Allocation Model (PAL) (Turhollow et al. 1985) used in earlier NMFFS studies (Lee, Das, and Leiby 1991; Das et al. 1988; Hadder et al. 1987). Both models link crude oil production in producing regions and refined products from processing regions with the region of demand. The model's calculations are guided by historical, worldwide regional flows of crude oils and products and by the desire to minimize transportation and refining costs. OTM is a personal-computer-based model capable of simulating nonlinear product demand schedules, and supply-demand equilibration is based on maximizing the sum of consumers' and producers' surpluses. However, OTM's regional representations of crude oil production, refining, and transportation activities are more aggregate than in the PAL model. ${ }^{3}$ The OTM forecasts of crude oil supplies and the production of refined products are used in an enhanced version of the RYM (Hadder and Davis 1991 ) to estimate detailed quantities, qualities, and costs of refined products from each region. RYM is a personal-computer-based linear program that represents regional refining operations. It includes 37 refinery processes, which can be used to produce more than 30 products from at least 100 crude oils.

The latest version of the OTM avsilable from the EIA was used for the analysis. Subsequent enhancements made to the OTM include (1) a routine for regional summary reports, (2) explicit regional representation of the Soviet Union and Eastern Europe ${ }^{4}$, and (3) updated values for the input parameters. China was included within the OTM region, the Far East. Appendix A lists sources of information and assumptions made for OTM enhancements. Most data sources are from the DOE's EIA publications and models.

\footnotetext{
${ }^{3}$ Free market economies are represented by 10 supply and demand regions and 11 refinery regions. Each supply region can have seven types of indigenous crude ôistinguished by API gravity and sulfur content. There are six different types of finished product demand categories.

'Definition of OTM regions: the U.S.; Canada; Japan; W. Europe; E Europe (Bulgaria, Czechoslovakia, East Germany, Hungary, Poland, and Romania); Middle East (Bahrain, Iran, Iraq, Kuwait, Oman, Qatar, Saudi Arabia, and United Arab Emirates); Latin America (Argentina, Bolivia, Brazil, Colombia, Ecuador, Mexico, Trinidad and Tobago, and Venezuela); Africa (Algeria, Cameroons, Egypt, Libya, Nigeria, and Tunisia); Far East (Australia, Brunei, China, India, Indonesia, Malaysia, New Zealand, Pakistan, Taiwan, and Thailand); and the U.S.S.R.
} 


\section{SCENARIO DESCRIPTION}

Two scenarios (i.e., BAU and LOIL) are considered for the year 2000; both assume that China, Eastern Europe, and the Soviet Union are free market economies for the purposes of international trade. The only major difference between the scenarios is in the level of the Soviet crude oil production and in higher levels of crude oil production in the Middle East, Latin America, Africa, and the Far East to compensate for the Soviet crude oil production loss. In addition, several sensitivity analyses of the BAU scenario were considered.

\subsection{BUSINESS AS USUAL (BAU)}

The BAU scenario for the year 2000 was based on EIA (1990a) supply and demand projections for non-U.S. regions, including the Soviet Union, Eastern Europe, and China. DOE (1991) was used for the U.S. "projections" of supply and demand. Total world oil consumption is assumed to be 68.7 MMBD. According to EIA (1990a), the U.S.S.R.'s supply for the year 2000 is assumed to be identical to its 1990 production level of $10.5 \mathrm{MMBD}$. The unchanged level of Soviet oil production in the year $\mathbf{2 0 0 0}$ may occur due to limited availability of investments required to boost production.

The DOE projection of U.S. oil production for the year 2000 is 9.3 MivíBD, $0.6 \mathrm{MMBD}$ higher than the corresponding EIA (1990a) projection. Assumptions made about measures to increase U.S. crude oil production include (1) the use of advanced oil recovery "echnology, made possible by new investments in federal and private sector research and development; (2) the environmentally responsible development of the coastal plain of the Arctic National Wildlife Refuge (ANWR); and (3) the implementation of the Administration's Outer Continental Shelf (OCS) leasing program. U.S. oil consumption is projected to be $18.4 \mathrm{MMBD}, 0.4 \mathrm{MMBD}$ lower than the corresponding EIA (1990a) projection. This reduction in consumption would come from the use of alternative fuels, the results of transportation research and development, improved passenger vehicle efficiency, and widespread use of reformulated gasoline resulting from the 1990 Clean Air Act. The reformulated gasoline is estimated to cost an additional 10 to 15 cents/gallon (Tahmassebi 1991), thereby causing pressure on gasoline demand growth. These supply and demand measures are aimed towards substantial reduction of U.S. dependence on insecure supplies, keeping oil import levels at less than the current level of $50 \%$ of U.S. consumption.

\subsection{BAU SENSITIVITY ANALYSES}

To assess the variability and stability of the model's projections in the BAU scenario in response to different market assumptions, seven sensitivity analyses for the BAU scenario in the year $\mathbf{2 0 0 0}$ were considered. Each sensitivity analysis was based on a variation of only one of the market parameters of the BAU scenario. For example, while considering lower refinery capacity utilization in Eastern Europe and the Soviet Union, all parameters except refinery capacity utilization rates in those specific two regions were identical to the values of the BAU scenario. The selection of the market parameters to which variations were made was aimed to encompass the uncertainty and variability of the energy prospects for the Soviet Union and Eastern Europe to the extent possible. The seven sensitivity analyses considered were: 
- The refinery capacity utilization rate is assumed to be $90 \%$ in Eastern Europe and the Soviet Union as compared to the $82 \%$ assumeci in the BAU scenario.

- The refinery capacity utilization rate is assumed to be $75 \%$ in Eastern Europe and the Soviet Union as compared to the $82 \%$ assumed in the BAU scenario.

- The crude oil and refined product transportation cost between North America (i.e., the United States and Canada) and the Soviet Union is assumed to be $25 \%$ higher than that used in the BAU scenario.

- The crude oil and refined product transportation cost between North America and the Soviet Union is assumed to be $25 \%$ lower than that used in the BAU scenario.

- The high demand for foreign exchange required for necessary investments in the energy industry and effective energy conservation measures are assumed to reduce Soviet Union and Eastern Europe demand by 25\%. Demand in these regions declines to $5.93 \mathrm{MMBD}$ and 1.58 MMBD, respectively, as compared to the corresfonding 7.9 MMBD and 2.1 MMBD BAU levels.

- The current energy demand growth is assumed to continue such that demands in the Soviet Union and Eastern Europe are 10\% higher. Demand in these regions increases to 9.87 MMBD and 2.63 MMBD, respectively, as compared to the corresponding BAU levels of 7.9 MMBD and 2.1 MMBD.

- U.S. supply and demand estimates of 8.7 MMBD and 18.8 MMBD, respectively, are based on ELA (1990a). Consequently, production is higher by $0.6 \mathrm{MMBD}$, and demand is lower by 0.4 MMBD compared with the DOE (1991) estimates used in the BAU scenario.

\subsection{LOW U.S.S.R. CRUDE OIL PRODUCTION (LOIL)}

The LOIL scenario is similar to the year 2000 BAU scenario (discussed above), with the exception that the current Soviet crude oil production decline trend would continue such that U.S.S.R. production could just meet its own demand in the year 2000. As discussed under Sect. 1, Soviet crude oil production has been declining during the last several years, from a level of 12.5 MMBD in 1987 to 10.5 MMBD last year. It is predicted that because of lack of availability of hard currency to make the necessary investments in the industry, it will be difficult for the Soviet Union in the coming years to reverse its current downward trend in crude oil production. Lippman and Potts (1991) and Sieff (1991) predict that loss of Iraqi oil imports in exchange for military materials and weapons and the continued lower crude oil production in the Soviet Union could force it to be a net importer of oil by as early as the end of 1993 . Soviet crude oil production in this scenario is 7.9 MMBD instead of the 10.5 MMBD assumed in the BAU scenario. Crude oil and refined product trade in the U.S.S.R. is still assumed to take place; imports are restricted to crude oil so that refineries use all domestic crude oils and additional foreign crude oils to utilize its remaining refining capacities. Soviet refining capacity is assumed to be no greater than the BAU level. No changes in crude oil production level from the BAU level are assumed for Eastern Europe and China. Regional consumption levels remain unchanged at the corresponding BAU scenario levels. 
This loss in crude oil production from the U.S.S.R. is met by market-based (price-driven) adjustments in the behavior of producers and consumers in the regions outside of the Soviet Union, where excess crude oil production capacity is available. In the OTM, the availability of the excess of BAU crude oil level was represented by marginal crude oil production cost ${ }^{5}$ curves for the Middle East, Latin America, Africa, and the Far East. Major countries in the Far East that were assumed to have the excess of BAU crude oil production capacities include Indonesia, Malaysia, and Australia/New Zealand. Higher crude oil production levels are assumed to be available in this scenario as a result of higher crude oil price.

${ }^{5}$ The following nonlinear marginal cost function of Leiby and Teisberg (1991) was used:

$$
\mathbf{P}=\mathrm{A}+\mathrm{B} /(\mathbf{C}-\mathrm{Q})
$$

where $P$ denotes the crude oil production cost and $Q$ denotes the associated quantity. The supply parameters $A, B$, and $C$ are determined by user input of three points along the supply curve. The parameter $C$ imposes an upper bound upon supplies. Average regional crude oil production cost and regional maximum sustainable crude oil production capacity were based on information available from EIA (19э1b) and EIA (1990a), respectively. 


\section{RESULTS}

Two scenarios (i.e., BAU and LOIL), in addition to sensitivity analyses of the BAU scenario for the year 2000 were evaluated using the OTM Model. Appendix B contains detailed results for the two scenarios considered: (1) changes in regional crude oil and refined product flows in the year 2000 with respect to the corresponding flows in the year 1989, and (2) a summary of refined product output in the 13 OTM world regions. These data are too voluminous to discuss in this section, but they provide the interested reader with details and insights into the geographic redistribution of petroleum trade and the output of refined products under the different scenarios. Results of the sensitivity analyses of the BAU scenario are not discussed in detail; only highlights of the results are presented here.

The OTM results in this section provide a general overview of forecasts for the year 2000 . The results of the two scenarios are provided in the following order: projected world oil supply and demand, projected U.S. petroleum supplies, projected world oil trade, and projected world refinery output. Results of the BAU scenario are discussed in terms of changes in corresponding activities for the year 1989. Discussions on the LOIL scenario results highlight the changes as compared to the BAU scenario. More specific analyses of the preferences of refiners to produce individual military fuels under these two scenarios are discussed by Hadder and Davis (1991). Highlights from results of sensitivity analyses of the BAU scenario are only discussed under Sect. 4.5.

\subsection{WORLD OIL SUPPLY AND DEMAND}

BAU: Figure 4.1 shows the regional petroleum supply and demand for the forecast year 2000 (EIA 1990a) and 1989 (EIA 1991a) that have been used in our analysis. Compared with the 1989 level, world oil production and consumption will increase by $8.1 \%$ and $4.2 \%,{ }^{6}$ respectively, in the year 2000. The forecasted world oil consumption level of $68.7 \mathrm{MMBD}$ (EIA 1990a) used in our analysis lies within the forecast range of 56.7 MMBD to 76.5 MMBD (DOE 1991). The consumption will decrease most notably in the Soviet Union as more petroleum exports are necessary to make the necessary investments in the industry. In the remaining regions, the consumption increase will range between $6 \%$ and $30 \%$. The intensity of oil use in developing nations (e.g., the Far East) will continue to be high for the next decade as these nations build a manufacturing base and transportation infrastructure. Conservation measures will temper U.S. consumption to a moderate increase (i.e., $1.1 \mathrm{MMBD}$, or $6.3 \%$ ).

Most oil production increases will come from the Middle East. The Soviet Union and the Far East are the only two regions that will experience a decline in their crude oil production levels. Decline in crude oil production in the Far East will not only be limited to China. Other major Far East crude oil producers such as Australia/New Zealand, Indonesia, and Malaysia will also experience a decline in their production levels if the current trend of lower crude oil price continues through the end of this century. As discussed in Sect. 3.1, several new oil developmental program initiatives will help the United States to reverse the current downward trend of oil production.

\footnotetext{
${ }^{6}$ Increase in world oil production and consumption in the year 2000 is not the same; for the United States, production is higher and consumption is lower than corresponding values projected by EIA (1990a). EIA (1990a) projections for oil production and consumption for all regions outside the United States are used.
} 


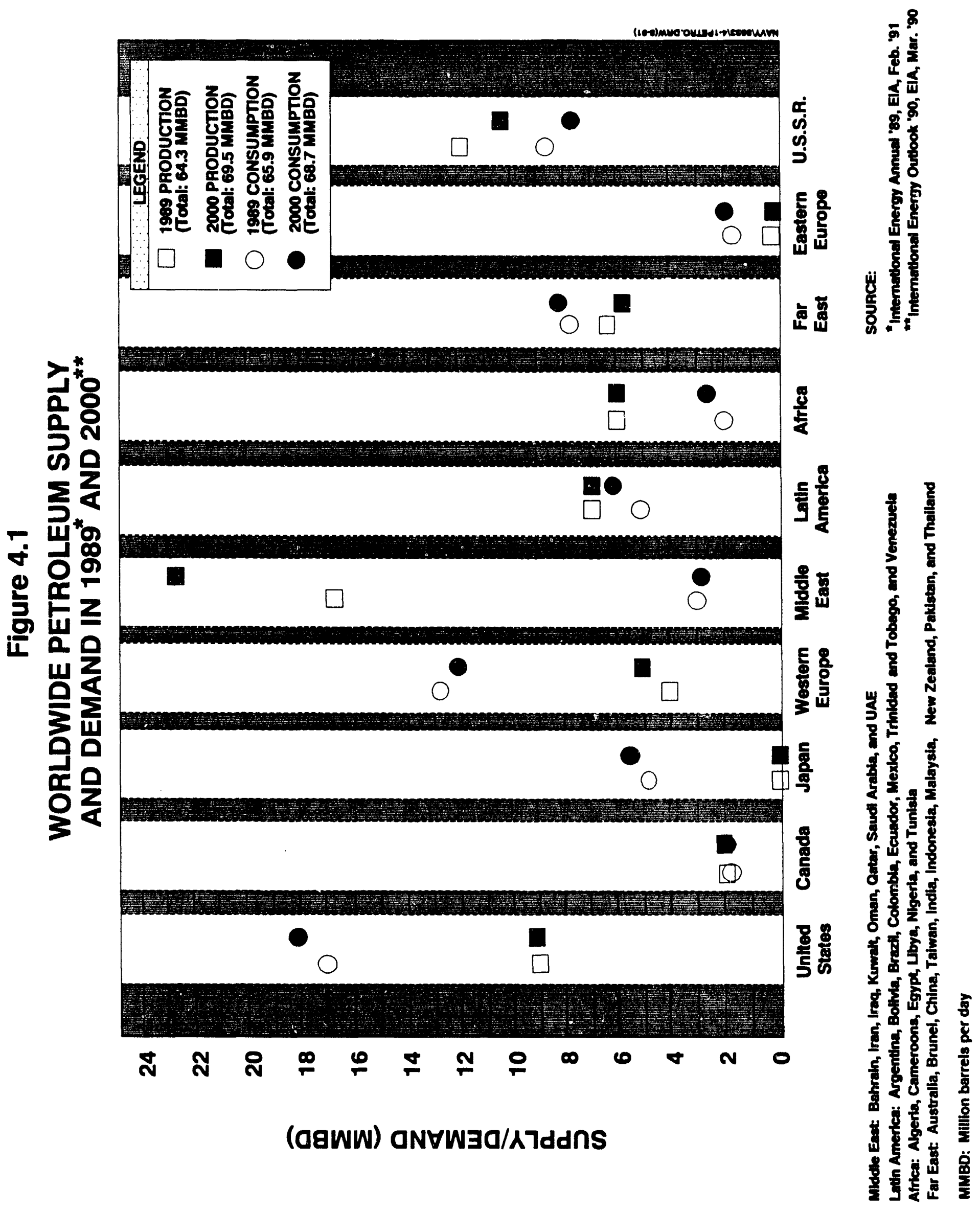


LOIL: Under the LOIL scenario, the Soviet crude oil production loss of 2.6 MMBD will be compensated by increased production from the Middle East, Latin America, Africa, and the Far East. As discussed in Sect. 3.3, the Soviet crude oil production loss is compensated by higher crude oil production than the BAU scenario level in the regions outside of the Soviet Union, where excess production capacity is available. More than half of the total Soviet crude oil production loss (i.e., $54.8 \%$ ) will be compensated for by production in Latin America; the Middle East will provide another 23.7\% of total loss. Increased crude oil production by major Far East crude oil producers such as Australia/New Zealand, Indonesia, and Malaysia will offset $17 \%$ of the total Soviet crude oil production loss.

\subsection{U.S. PETROLEUM SUPPLIES}

BAU: Table 4.1 shows U.S. petroleum supplies in 1989 and for the year 2000 under the BAU and LOIL scenarios. Under the BAU scenario, domestic crude oil production and total petroleum imports will increase by $0.1 \mathrm{MMBD}$ and $1.2 \mathrm{MMBD}$, respectively, compared with corresponding 1989 levels. Higher imports of crude oils and refined products (i.e., $12.3 \%$ and $23.3 \%$, respectively) than corresponding 1989 levels will be coming to the United States. Imports will account for $49 \%$ of total petroleum requirements. The Middle East will contirue to be the major crude oil supplier to the United States, but the increase in total petroleum imports will come from regions other than the Middle East and Canada. An estimated 0.1 MMBD of Soviet crude oil will be imported to the United States. A significantly higher level of 300 thousand barrels per day (MBD) of refined product imports will be coming from Japan. Eastern Europe will also help to meet the demand for increased refined products.

Table 4.1. U.S. petroleum supply (million barrels per day)

\begin{tabular}{|c|c|c|c|c|c|c|}
\hline \multirow{3}{*}{ Regions } & \multirow{2}{*}{\multicolumn{2}{|c|}{$1989^{c}$}} & \multicolumn{4}{|c|}{2000} \\
\hline & & & \multicolumn{2}{|c|}{ BAU" } & \multicolumn{2}{|c|}{ LOIL $^{b}$} \\
\hline & $\begin{array}{c}\text { Crude } \\
\text { oil }\end{array}$ & $\begin{array}{l}\text { Refined } \\
\text { products }\end{array}$ & $\begin{array}{c}\text { Crude } \\
\text { oil }\end{array}$ & $\begin{array}{l}\text { Refined } \\
\text { products }\end{array}$ & $\begin{array}{c}\text { Crude } \\
\text { oil }\end{array}$ & $\begin{array}{l}\text { Refined }^{d} \\
\text { products }\end{array}$ \\
\hline Domestic & 9.2 & 15.8 & 9.3 & 15.9 & 9.3 & 14.9 \\
\hline $\begin{array}{l}\text { Foreign } \\
\text { Canada }\end{array}$ & 0.6 & 0.3 & 0.6 & 0.3 & 0.6 & 0.3 \\
\hline Japan & 0.0 & 0.0 & 0.0 & 0.3 & 0.0 & 0.3 \\
\hline Western Europe & 0.3 & 0.3 & 0.5 & 0.3 & 0.3 & 0.3 \\
\hline Middle East & 1.8 & 0.1 & 1.7 & 0.1 & 1.9 & 0.1 \\
\hline Latin America & 1.4 & 1.1 & 1.5 & 1.1 & 1.2 & 1.1 \\
\hline Africa & 1.3 & 0.2 & 1.5 & 0.2 & 1.2 & 0.2 \\
\hline Far East & 0.3 & 0.1 & 0.4 & 0.1 & 0.4 & 0.1 \\
\hline Eastern Europe & 0.0 & 0.0 & 0.0 & 0.2 & 0.0 & 0.0 \\
\hline U.S.S.R. & 0.0 & .05 & 0.1 & .05 & 0.0 & 1.0 \\
\hline Total Foreign & 5.7 & 2.15 & 6.4 & 2.65 & 5.6 & 3.4 \\
\hline
\end{tabular}

"BAU: Business as usual scenario

'LOIL: Low U.S.S.R. crude oil production scenario

'Source: EIA (1990b), EIA (1991a).

'Numbers under "Domestic Refined Products" indicate domestic refinery output 
LOIL: Under the LOIL scenario, total U.S. petroleum imports will not change significantly from the BAU scenario. A decline in crude oil imports will complement a similar level of increase in refined product imports. As other regions that import Middle East crude oil reduce their imports by increasing their own crude oil production and refinery output, more crude oil will be available to the United States from the Middle East (1.9 MMBD instead of 1.7 MMBD under the BAU scenario). However, total crude oil imports will not increase as compared with the BAU scenario. Lower crude oil imports will cause a decline of $1.0 \mathrm{MMBD}$ in refinery output. The reduced refinery output will be balanced by increasing refined product imports. The Soviet Union will provide 30\% of total refined product imports as there will be reduction in the Soviet refined product exports demand in other regions due to either more refinery activities or less refined product exports.

\subsection{WORLD OIL TRADE}

Table 4.2 shows world petroleum trade in 1989 and for the two scenarios (BAU and LOIL) considered here for the year 2000. Specific sources and destinations of world petroleum for the BAU and LOIL scenarios are shown in Fig. 4.2 and 4.3, respectively. Detailed regional trade flows for the two scenarios are provided in Appendix B.

Table 4.2 Worldwide petroleum trade (million barrels per day)

\begin{tabular}{lcccccc}
\hline & \multicolumn{2}{c}{$1989^{c}$} & \multicolumn{2}{c}{ BAU $^{\mathbf{a}}$} & \multicolumn{2}{c}{ LOIL $^{\mathbf{b}}$} \\
Regions & \multicolumn{1}{c}{ Imports } & Exports & Imports & Exports & Imports & Exports \\
\hline United States & 7.9 & 0.6 & 9.1 & 0.8 & 9.0 & 0.6 \\
Canada & 0.6 & 0.9 & 1.4 & 1.7 & 1.0 & 1.2 \\
Western Europe & 8.7 & 1.0 & 8.3 & 1.4 & 8.0 & 1.0 \\
Middle East & 0.0 & 12.2 & 0.0 & 16.9 & 0.0 & 17.7 \\
Latin America & 1.1 & 3.3 & 2.5 & 3.6 & 1.0 & 4.0 \\
Africa & 0.5 & 4.4 & 1.3 & 4.8 & 1.0 & 4.6 \\
Japan & 4.6 & 0.0 & 5.8 & 0.3 & 5.8 & 0.3 \\
Far East & 2.6 & 1.6 & 4.1 & 1.7 & 3.5 & 1.5 \\
Eastern Europe & 1.8 & 0.1 & 2.2 & 0.5 & 2.1 & 0.4 \\
U.S.S.R. & 0.3 & 3.8 & 1.4 & 4.1 & 1.8 & 1.8 \\
\hline
\end{tabular}

"BAU: Business as usual scenario.

'LOIL: Low U.S.S.R. crude oil production scenario.

'Sources: $\quad$ EIA (1990b), EIA (1991a), EIA (1991c). 


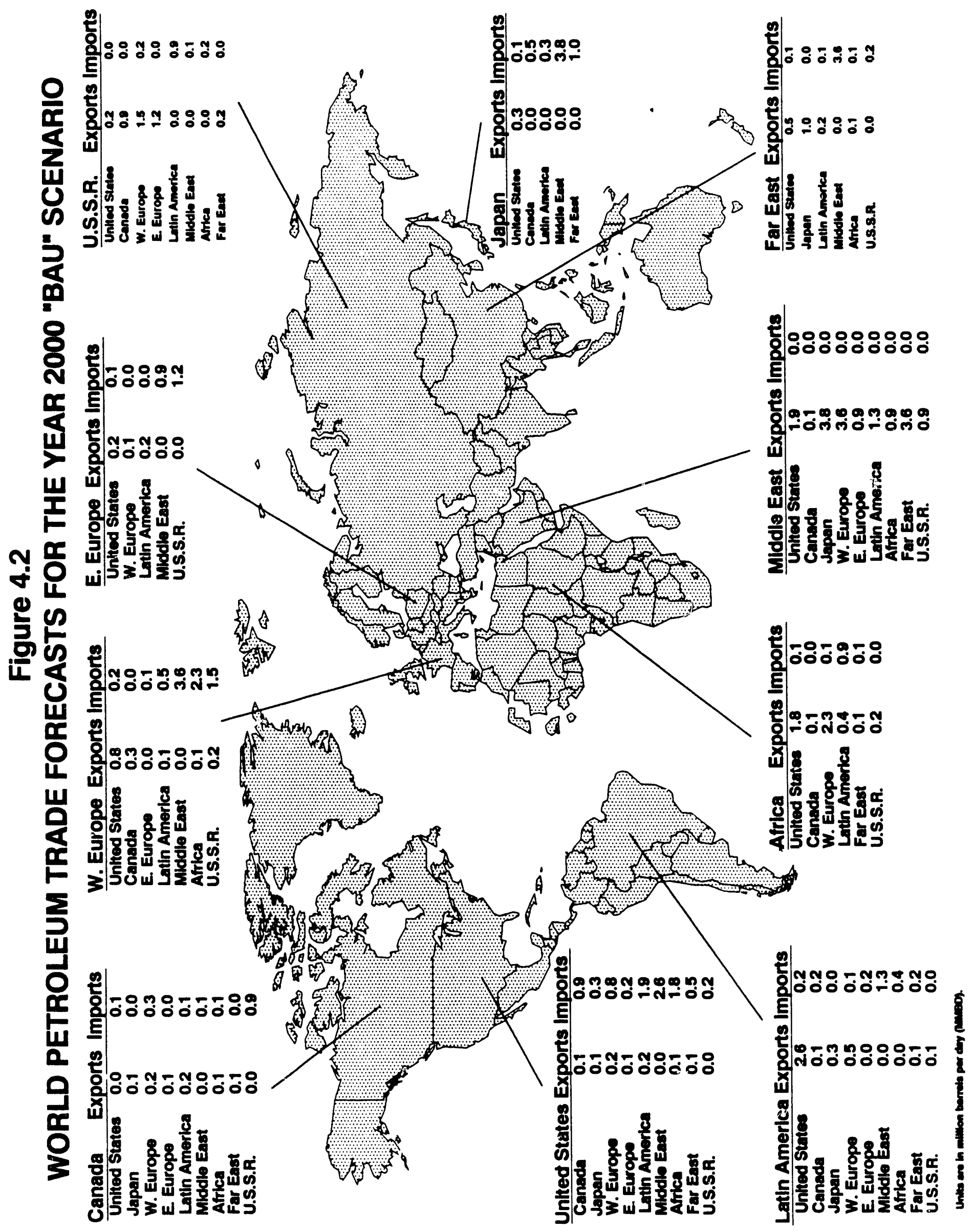




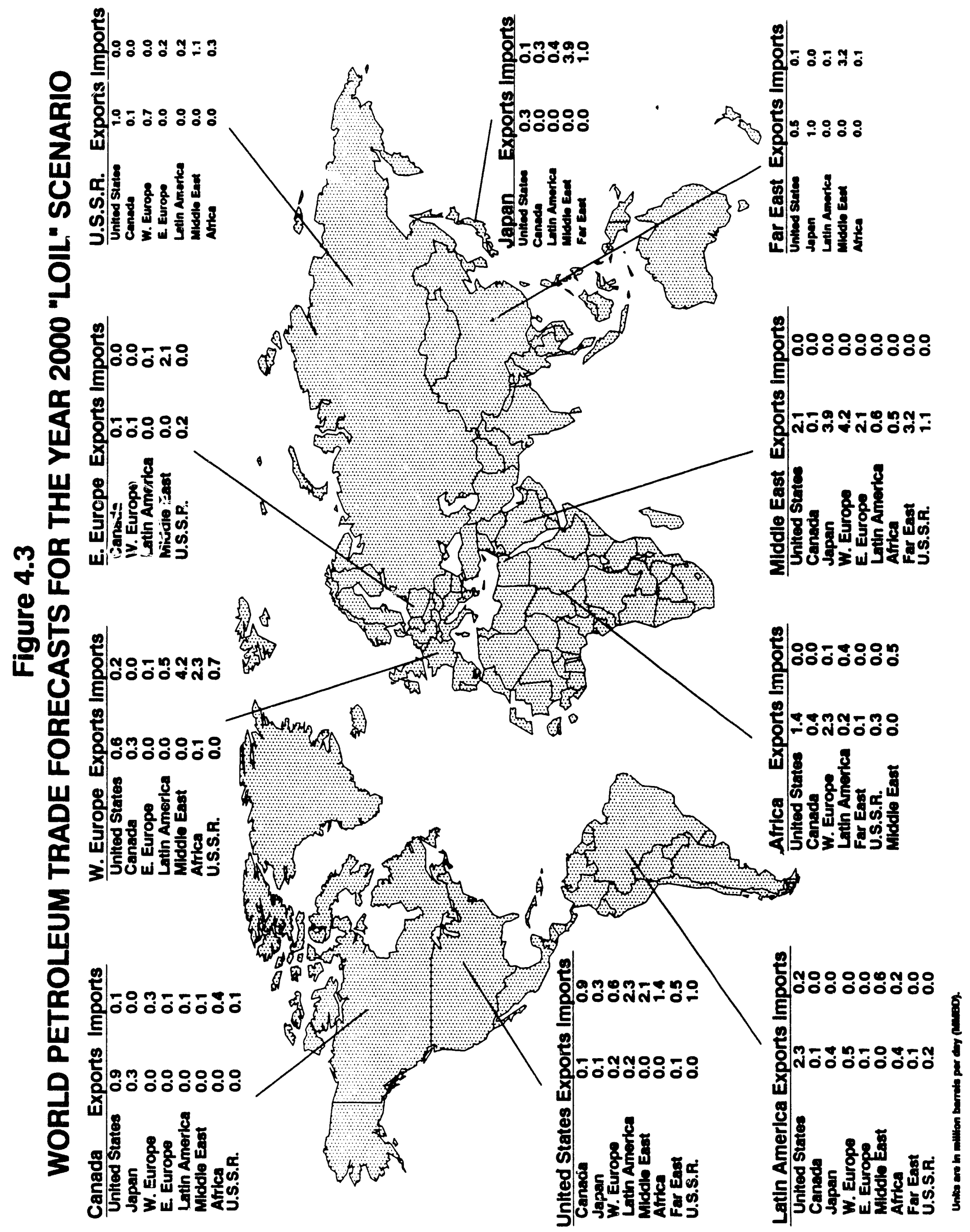


In the year 2000 , the volume of petroleum trade activities will be higher, although net trade activities will not be significantly different than 1989 . The following paragraphs highlight region specific trade flows. Readers not interested in regional details may skip this subsection and can find the discussion of major results in Sect. 5. As for discussion of results in earlier sections, results of the BAU scenario are discussed similarly (i.e., in terms of changes in corresponding activities for the year 1989). Discussions on the LOIL scenario results highlight the changes as compared to the BAU scenario.

\section{United States}

BAU: U.S. net petroleum imports will increase moderately, by $1.0 \mathrm{MMBD}$. The greatest increase in crude oil imports will come from Western Europe, Africa, and the Soviet Union. Primarily, Japan and Eastern Europe will provide increased product imports to meet increased demand in the United States. U.S. export levels will increase by 0.2 MMBD to supply residual fuel oil and coke for Eastern Europe and Africa.

LOIL: The level of net petroleum imports will not change significantly under the LOIL scenario. As discussed in Sect. 4.2, crude oil imports will decrease and refined products imports will increase (1.0 MMBD from the Soviet Union and 0.3 MMBD from Japan).

\section{Canada}

BAU: Canada will remain a nut petroleum exporter at the same level as in 1989 . However, there will be changes in its trade patterns due to sensitivity of refined product availability to crude mix quality and refinery configuration. Petroleum imports will increase by $0.8 \mathrm{MMBD}$ as a result of imports from the Soviet Union (0.3 MMBD crude oil and $0.5 \mathrm{MMBD}$ refined products, mostly gasoline). Canada's exports will likewise increase by $0.8 \mathrm{MMBD}$, all in the form of refined products (middle distillates and residual fuel oil) to Japan and Latin America.

LOIL: Under the LOIL scenario, $94 \%$ of the Soviet petroleum exports to Canada are lost. Most of the increased petroleum imports now come from Africa, where crude oil production will increase. Eastern Europe will supply $61 \mathrm{MBD}$ of refined products.

\section{Western Europe}

BAU: Increased crude oil production and lower consumption will cause a decline in Western Europe's net petroleum imports (approximately 6.9 MMBD as compared to 7.7 MMBD in 1989). The decline will occur mainly in crude oil imports from Africa and the Middle East. The United States and the Soviet Union will receive a total of $0.3 \mathrm{MMBD}$ more crude oil from Western Europe (as compared with the 1989 level).

LOIL: Middle East crude oil supplies to Western Europe will increase by 0.6 MMBD (for a total of 3.7 MMBD) because of the Soviet crude oil import loss under the LOIL scenario. Western Europe's crude oil exports to the United States and the Soviet Union also will decline to offset the lost Soviet crude oil imports. No significant changes from the BAU scenario in refined product trade will occur under this scenario. 


\section{Middle East}

BAU: The Middle East will continue to be the dominant petroleum supplier in the year 2000 (crude oil and refined product exports will increase by $37.5 \%$ and $44.4 \%$, respectively). An increase in crude oil exports to Japan, Eastern Europe, Latin America, Africa, the Far East, and the Soviet Union will occur. The Far East will receive more (i.e., 0.3 MMBD) than any other region from the Middle East's total increased level of refined product exports.

LOIL: Under the LOIL scenario, the increased level of Middle East petroleum will supply the Soviet Union and the regions that receive the Soviet crude oil imports under the BAU scenario. All of the Eastern Europe crude oil demand will be satisfied by the Middle East. Refined product exports to the Far East will increase by $33.4 \%$.

\section{Latin America and Africa}

BAU: Latin America and Africa will be net petroleum exporters to a lesser extent under the BAU scenario, compared with 1989. Increased crude oil imports to these regions will come from the Middle East. Refined product imports to Latin America will increase by 0.8 MMBD (or 463\%), supplied in varying amounts by almost all regions. On the other hand, Latin America and, to a greater extent, Africa will supply $0.3 \mathrm{MMBD}$ of ( $78.5 \%$ of total) refined product imports to the Soviet Union.

LOIL: As discussed in Section 4.1, crude oil production will increase in these regions under the LOIL scenario. Crude oil imports from the Middle East to these regions will decrease. The increase in Latin American crude oil production will be sufficient for its own needs. Refined product exports from this region will increase by $0.6 \mathrm{MMBD}$ or $44 \%$, with most exports going to Japan and Africa. Latin America will become the major source of refined product imports to Africa.

\section{Japan and Far East}

BAU: Japan and the Far East will increase their petroleum imports and will continue to meet their major share of petroleum consumption by imports, mainly from the Middle East. The share of Middle East petroleum imports will be $66 \%$ in Japan and $88 \%$ in the Far East. However, Japan will export $0.3 \mathrm{MMBD}$ of refined products (mainly gasoline and naphtha) to the United States, as it will refine higher volumes of crude to meet its demand for middle distillates.

LOIL: In the LOIL scenario, net petroleum imports of the Far East will decrease because of increased crude oil production. No significant changes will occur in sources of crude oil for Japan. Because of increased refinery activity (a higher level of domestic crude oil production) in Latin America, that region's exports of products to Japan will compensate for lost exports from Canada.

\section{Eastern Europe}

BAU: Eastern Europe will import more (i.e., 0.4 MMBD) of both crude oils and refined products. It will import a total of $1.9 \mathrm{MMBD}$ of crude oil in the year $2000,45 \%$ of which will be imported from the Middle East and the rest from its old trading partner the Soviet Union. Eastern Europe will become a net exporter (i.e., $203 \mathrm{MBD}$ ) of refined products; exports will come to the United States, Western Europe, and Latin America. 
LOIL: Lower Soviet crude oil production under the LOIL scenario will result in all crude oil imports coming from the Middle East. Refined products exported to the United States and Latin America under the BAU scenario will be diverted to the Soviet Union in the LOIL scenario.

\section{Soviet Union}

BAU: In the Soviet Union, petroleum imports will increase by $1.1 \mathrm{MMBD}(367 \%)$ in thic year 2000. The Middle East and Western Europe will be sources for crude oil imports. Crude oil exports will not increase; however, destinations will change. The U.S. and Canada will receive $0.2 \mathrm{MMBD}$ and 0.9 MMBD, respectively, of Soviet crude petroleum exports. Higher levels of the Soviet petroleum exports to the United States and Canada occur as its exports to Eastern Europe decline. Imports of refined products will be 0.4 MMBD (almost insignificant in 1989), with more than $50 \%$ coming from Africa.

LOIL: Total loss of Soviet crude oil exports under the LOIL scenario will cause the Soviet Union to import an additional $0.2 \mathrm{MMBD}(17 \%)$ of crude oil, with all supplies coming from the Middle East. However, there will be no net petroleum imports. Increased crude oil imports will go into increased refined product exports. At the expense of reduction in Soviet exports to other regions, 1.0 MMBD of refined product exports to the United States will occur.

\subsection{WORLD REFINERY OUTPUT}

Table 4.3 shows world regional output of refined netroleum products for 1989 and the two scenarios in the year 2000. Appendix $C$ details the product slates of regional world petroleum refineries for the two scenarios.

Table 4.3. World output of refined petroleum products (million barrels per day)

\begin{tabular}{lrrr}
\hline & $1989^{\circ}$ & & 2000 \\
Regions & & BAU & LOIL $^{\mathrm{b}}$ \\
\hline United States & 15.8 & 15.9 & 14.9 \\
Canada & 1.7 & 2.3 & 2.0 \\
Japan & 3.3 & 3.6 & 3.6 \\
Western Europe & 12.5 & 10.2 & 10.3 \\
Middle East & 4.2 & 5.1 & 5.0 \\
Latin America & 5.8 & 6.4 & 7.9 \\
Africa & 2.1 & 3.1 & 3.1 \\
Far East & 6.9 & 8.3 & 8.1 \\
Eastern Europe & 2.4 & 2.2 & 2.3 \\
U.S.S.R. & 9.7 & 8.8 & 8.7 \\
\hline
\end{tabular}

"BAU: Business as usual scenario.

'LOIL: Low U.S.S.R. crude oil production scenario.

'Source: EIA (1991a), Eastern Bloc Research, Ltd. (1991), Movit (1991).

(1988 numbers used in cases where data are unavailable). 
BAU: Under the BAU scenario, refinery output will be higher in most of the 10 world regions except for Western Europe, the U.S.S.R., and Eastern Europe, compared with the corresponding 1989 level. The decrease in consumption in these former two regions (as observed in Sect. 4.1) will cause a significant decline in their refinery output. Canada and Africa are the two regions where increases in refinery output will be high, at $35 \%$ and $48 \%$, respectively. No significant change in refinery output is projected for the United States.

LOIL: Lower Soviet crude oil production under the LOIL scenario vill cause a decline in the refinery output of the United States, Canada, the Middle East, the Far East, and the Soviet Union. Import demand for refined products of Latin America, Africa, and the Far East from these five regions decreases. Because of the increased indigenous crude oil production, a larger share of demand in Latin America, Africa, and the Far East is now being met dornestically. The increased crude oil production from the Middle East will be used to increase crude oil exports instead of refinery output as seen in Table 4.2. Refinery output in the U.S.S.R. does not change much. The U.S.S.R. will continue to maintain the same level of refined product trade by importing more crude oil from the Middle East. Refinery output in Eastern Europe will increase by 0.1 MMBD.

\subsection{BAU SENSITIVITY ANALYSIS}

As discussed in Sect. 3.2, seven sensitivity analyses varied the values of some of the key assumptions used in the year 2000 BAU scenario. The variability or stability of 10 key model projections found to be significantly different in the BAU scenario than current (1989) conditions was considered. Table 4.4 lists those 10 key model projections along with the variability observed in these projections under the seven sensitivity analyses considered here. The results of the LOIL scenario (as eighth sensitivity analysis case) are also included in Table 4.4 as they indicate variation only in the level of Soviet crude oil production from the BAU scenario.

\section{U.S. Petroleum Imports}

Total net U.S. petroleum imports will remain unchanged under most sensitivity scenarios. The increase in crude oil imports will be compensated for by a reduction in net refined product imports. For example, under a lower Soviet and Eastern European refinery utilization rate of 75\%, more Soviet crude oil available to the U.S. refineries would help to similarly reduce the U.S. net refined product imports. The effect of a higher (90\%) Soviet and Eastern Europe refinery utilization rate on U.S. imports would be opposite, but the level would be considerably lower due to inadequate Soviet refincry configuration required to satisfy the U.S. demand for specific refined products (mostly gasoline and middle distillates). Higher demand in the Soviet Union and Eastern Europe will be met by increased refined product imports (more Soviet crude oil available to the U.S. refineries helps in reducing the net U.S. refined product imports); lower demand in the Soviet Union and Eastern Europe will cause an increase in the Soviet refinery activities (more refined product exports available from the Soviet Union and Eastern Europe cause an increase in the net U.S. total refined product imports). Lower U.S. crude oil production and higher consumption, according to EIA (1990) estimates, will cause the United States to import an additional 1.03 MMBD of petroleum (crude oil: 0.83 MMBD; refined product: 0.2 MMBD). 


\begin{tabular}{|c|c|c|c|c|c|c|c|c|c|c|c|c|}
\hline \multicolumn{2}{|l|}{ 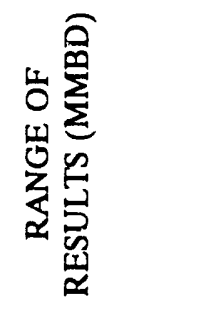 } & \multirow[t]{2}{*}{ 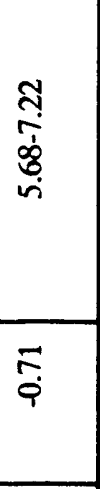 } & \multirow{2}{*}{ 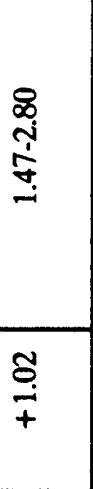 } & \multirow{2}{*}{$\begin{array}{l}\frac{m}{0} \\
\hat{0} \\
\frac{n}{9}\end{array}$} & \multirow{2}{*}{$\begin{array}{l}\frac{\tilde{1}}{\dot{5}} \\
\frac{8}{+}\end{array}$} & \multirow{2}{*}{ 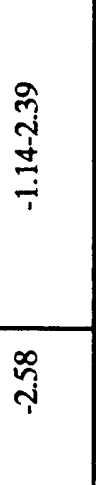 } & \multirow{2}{*}{ 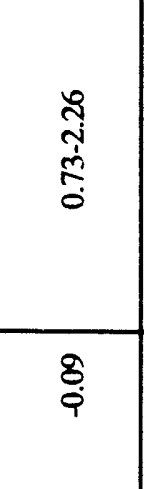 } & \multirow{2}{*}{$\begin{array}{l}\text { ô } \\
\text { ì } \\
\frac{\vec{T}}{+}\end{array}$} & \multirow{2}{*}{$\begin{array}{c}\bar{m} \\
0 \\
0\end{array}$} & \multirow{2}{*}{ 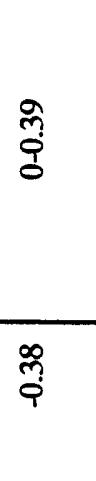 } & \multirow{2}{*}{ 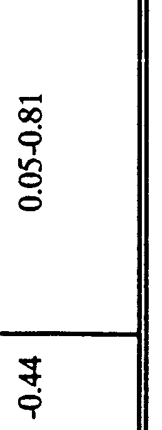 } & \multirow{10}{*}{ 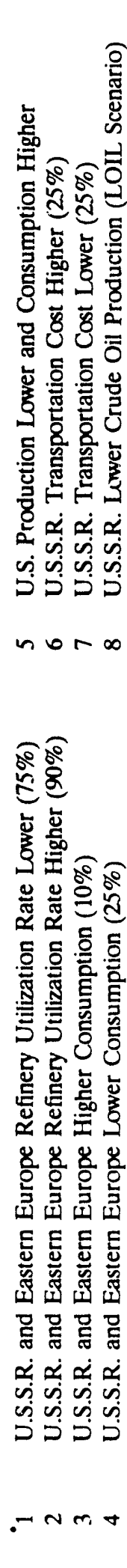 } \\
\hline \multirow{8}{*}{ 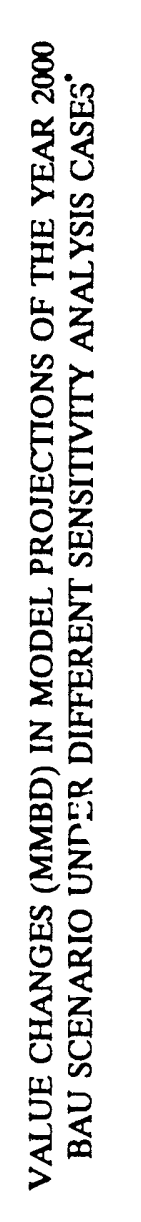 } & $\infty$ & & & & & & & & & & & \\
\hline & $r$ & $\frac{5}{+}$ & $\frac{5}{9}$ & $\stackrel{\substack{\infty \\
+}}{+}$ & $\stackrel{\text { ஜ̊ }}{+}$ & $\begin{array}{l}\delta_{0} \\
+\end{array}$ & চه & 0 & $\stackrel{\Xi}{\circ}$ & ণ্ণ & ஜ̊ & \\
\hline & 0 & চ̊ & $\begin{array}{l}\text { o } \\
0 \\
+\end{array}$ & $\stackrel{n}{i}$ & 0 & $\begin{array}{l}\mathbb{0} \\
0 \\
+\end{array}$ & 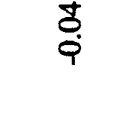 & $\stackrel{\bar{\varphi}}{\grave{Q}}$ & $\begin{array}{l}\widetilde{O} \\
\stackrel{+}{+}\end{array}$ & $\stackrel{m}{9}$ & ষ্ট্র & \\
\hline & $n$ & $\begin{array}{l}\infty \\
0 \\
\dot{+} \\
+\end{array}$ & $\begin{array}{l}\text { ్ㅜ } \\
\text { + }\end{array}$ & $\begin{array}{l}\tilde{n} \\
\tilde{+} \\
+\end{array}$ & $\begin{array}{l}8 \\
0 \\
+\end{array}$ & $\begin{array}{l}\overline{0} \\
\dot{+}\end{array}$ & 웅 & $\begin{array}{l}\mathscr{0} \\
\stackrel{\infty}{+} \\
+\end{array}$ & $\frac{ \pm}{\dot{0}}$ & 0 & ¿o. & \\
\hline & $\forall$ & ণ্ণি & $\begin{array}{l}5 \\
0 \\
+\end{array}$ & $\stackrel{\check{\delta}}{\grave{Q}}$ & $\stackrel{8}{\circ}$ & $\begin{array}{l}\dddot{\alpha} \\
0 \\
+\end{array}$ & $\begin{array}{l}8 \\
0 \\
+\end{array}$ & 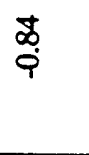 & $\begin{array}{l}8 \\
0 \\
+\end{array}$ & $\begin{array}{l}\overline{0} \\
+ \\
+\end{array}$ & $\stackrel{\widetilde{N}}{\stackrel{+}{+}}$ & \\
\hline & $m$ & $\begin{array}{l}\text { O } \\
\text { S } \\
+\end{array}$ & $\bar{m}$ & $\tilde{\hat{o}}$ & 0 & $\begin{array}{l}\infty \\
\hat{\imath} \\
+\end{array}$ & $\begin{array}{l}\tilde{n} \\
\hat{i}\end{array}$ & $\begin{array}{l}\hat{0} \\
\stackrel{+}{+}\end{array}$ & §̊ & 0 & $\frac{7}{9}$ & \\
\hline & $N$ & $\begin{array}{l}8 \\
8 \\
\end{array}$ & $\begin{array}{l}\tilde{0} \\
\text { + }\end{array}$ & $\stackrel{0}{0}$ & 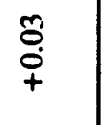 & $\begin{array}{l}\text { : } \\
\dot{q}\end{array}$ & 0 & \begin{tabular}{l}
$\forall$ \\
\multirow{0}{+}{} \\
+
\end{tabular} & 0 & 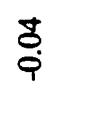 & 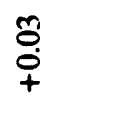 & \\
\hline & - & $\begin{array}{c}\text { ָ̊ } \\
\stackrel{+}{+}\end{array}$ & ָָ & $\begin{array}{l}\text { tr } \\
\text { o } \\
+\end{array}$ & 0 & $\begin{array}{l}\tilde{n} \\
0 \\
+\end{array}$ & $\begin{array}{l}n \\
\text { on } \\
0\end{array}$ & $\stackrel{5}{9}$ & 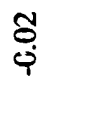 & 0 & 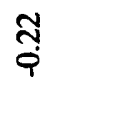 & \\
\hline 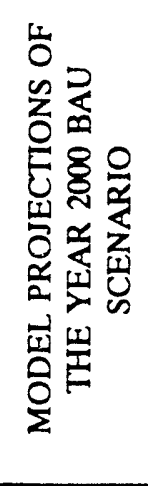 & & 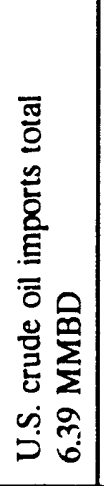 & 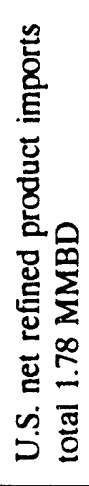 & 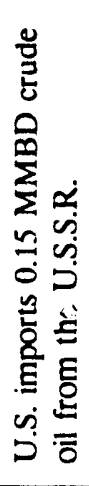 & 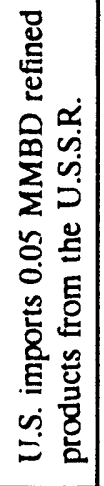 & 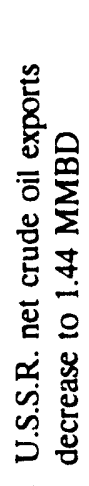 & 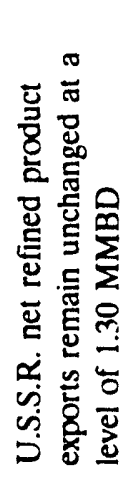 & 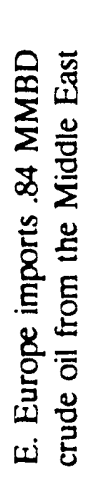 & 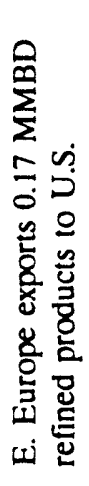 & 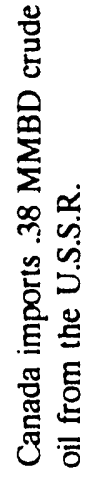 & 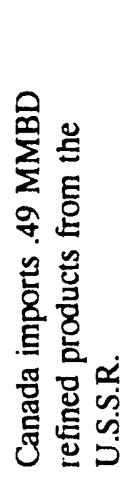 & \\
\hline
\end{tabular}




\section{U.S.S.R. Petroleum Imports to the U.S.}

The United States will import both crude oils and refined products from the Soviet Union under most sensitivity analysis cases. Total levels of imports vary from 0 to $2.0 \mathrm{MMBD}$. Lower transportation costs between the United States and the Soviet Union will necessitate maximum crude oil imports, whereas maximum refined product import will occur under the LOIL scenario. Under most sensitivity analysis cases, crude oil imports will be significantly higher than refined product imports. Higher transportation costs and lower Soviet crude oil production will limit Soviet petroleum coming into the United States.

\section{U.S.S.R. Petroleum Imports to Canada}

Canada will import comparatively more refined products than crude oils from the Soviet Union. Imports to Canada will be lost almost completely under the LOIL scenario. The lower consumption level in the Soviet Union and Eastern Europe will permit the maximum amount of Soviet petroleum (crude oils: $0.39 \mathrm{MMBD}$; refined product: $0.81 \mathrm{MMBD}$ ) imports to enter Canada. It is interesting to note that under lower transportation cost between the Soviet Union and Canada, the U.S.S.R. petroleum exports to Canada will not increase, as most of the increased Soviet petroleum exports will come to the United States. Comparatively, less variability in the amount of crude oil imports will occur under various sensitivity analysis cases.

\section{U.S.S.R. Petroleum Exports}

Total Soviet net petroleum exports will remain unchanged under most sensitivity analysis cases. For example, under the lower refinery utilization rate of $75 \%$, the loss of $0.55 \mathrm{MMBD}$ of net refined product export will be compensated for by 0.57 MMBD higher net crude oil export. As discussed earlier, higher consumption in the Soviet Union and Eastern Europe will be satisfied by the increase in refined product imports and financed by its increased crude oil exports. A maximum amount of 4.65 MMBD of net Soviet petroleum exports will be available under the lower consumption in the Soviet Union and Eastern European sensitivity analysis case. Net petroleum exports will almost disappear from the Soviet Union because of its lower crude oil production in the LOIL scenario. Because of crude oil imports into the Soviet Union, refinery activity, and hence refined product exports, will not be affected due to the loss of domestic crude oil production. Changes in the transportation cost between North America and the Soviet Union will not cause significant changes in the level of the Soviet petroleum exports, but destinations will change, as seen earlier.

\section{Eastern Europe Petroleum Imports}

Eastern Europe will receive a large portion of its total crude oil imports from the Middle East under most sensitivity analysis cases. No Middle East crude oil supplies will be necessary in Eastern Europe when petroleum demand in the Soviet Union and Eastern Europe is 25\% lower. Lower levels of U.S.S.R. crude oil production in the LOIL scenario will force Eastern Europe to obtain its 2.05 MMBD of crude oil supplies from the Middle East. Eastern Europe will export refined products to the United States in all cases, except under the LOIL scenario in which the refined product exports will be diverted to the Soviet Union. Eastern Europe will export up to $0.31 \mathrm{MMBD}$ of refined product to the United States under the sensitivity analysis case with low U.S. crude oil production but high consumption. Under the same situation, Middle East crude oil exports to Eastern Europe will increase by $0.82 \mathrm{MMBD}$ as more U.S.S.R. crude oil supplies are now being diverted to the United States to compensate for low U.S. production. 


\section{CONCLUSIONS}

This report presents forecasts of world petroleum activities under normal market (i.e., BAU) conditions for the year 2000. The analysis considered two primary scenarios. The only difference in the other scenario (i.e., LOIL) from the BAU scenario is in the level of Soviet crude oil production and in higher crude oil production levels in the Middle East, Latin America, Africa, and the Far East to balance the Soviet crude oil production loss. Several additional sensitivity analyses of the BAU scenario were considered in order to assess the variability or stability of some of key model projections of the BAU scenario.

EIA's forecasts of worldwide petroleum production and consumption for the year 2000 used in our analysis present only a few interesting behaviors. Under the BAU scenario, crude oil production is forecast not to decline except in two regions compared to the 1989 level: the U.S.S.R. and the Far East. Soviet crude oil production is assumed to remain unchanged from last year's level of 10.5 MMBD as great uncertainty remains with the availability of necessary future investments. Current trends toward lower crude oil prices will cause production declines in major oil producing regions of the Far East. Vulnerability of the rest of the world to the Middle East supply will continue. The increased crude oil production from the Middle East is forecast to be $35.5 \%$ higher than the 1989 level. Total growth in world oil demand continues in the year 2000 at a level $4.2 \%$ higher than the 1989 level. Demand growth is slower in most OECD countries than in developing countries. The Far East and Japan account for $43 \%$ of total world demand growth in 2000 . The East-West Center (Vervalin 1990) and DOE (1991) also predict growth in the Asia-Pacific region, the area from which the greatest demand for oil will come.

About half of the replacement for loss of crude oil under the LOIL scenario will come from Latin America. Crude oil from Latin America will help to replace the same quality of crude lost. Although crude oil from the Middle East was available, it was heavier than the lost Soviet crude. Interestingly, during the Iraqi invasion of Kuwait, the barrel-for-barrel replacement of the embargoed crude oil coming predominantly from Saudi Arabia and the United Arab Emirates was not sufficiently effective to solve the crisis. The replacement oil was heavier and "sourer" (higher in sulfur content) than the lost oil. Crude oil quality can be as important an issue as quantity.

Under the BAU scenario, as compared to 1989, interesting changes occur in worldwide trade patterns. U.S. imports will increase moderately from $46 \%$ in 1989 to $49 \%$ in the year 2000 if the current crude oil production level of around 9.3 MMBD is maintained. Sources of major imports wili remain the same. However, a significantly higher level of imports will be coming from Japan, the Soviet Union, and Eastern Europe. Not many changes are forecast for Canada and Western Europe. The Soviet Union will become the new source for crude oil and refined product imports for Canada (a total of 0.8 MMBD). The increased level of Western Europe (i.e., mainly North Sea) crude oil production, combined with no substantial growth in demand, will cause its net petroleum imports to decrease by $10.4 \%$ (compared with 1989). The major share of consumption in Japan and the Far East will continue to be satisfied by Middle East imports. Total Middle East imports to these regions will increase by 20\% (Japan) and 75\% (the Far East). Indigenous production in Latin America and Africa will not change much, although consumption increases in these regions will be substantial. Net petroleum exports will decline in these regions (e.g., in Latin America by as much as $51 \%$ from its 1989 level). Decline in Soviet crude oil production will cause a reduction of $23 \%$ in its net petroleum exports compared to the 1989 level. The U.S. and Canada will emerge as new significant oil trading 
partners of the Soviet Union. Nearly half of Eastern Europe's crude oil imports will come from the Middle East. Refinery activities will increase, and a portion of Eastern Europe refined products export will come to the United States.

There are considerable shifts in worldwide trade patterns under the LOIL scenario from the BAU scenario as crude oil production increases in the Middle East, Latin America, the Far East, and Africa to offset the Soviet crude oil production loss. Net petroleum exports will increase in these four regions where crude oil production increases. The Middle East supply will replenish the lost Soviet crude oil exports, including all of the Eastern Europe crude oil demand as all of the increased crude oil production from Latin America will go to satisfy its demand. U.S. net petroleum imports will not change significantly. However, increased refined product imports will occur at the expense of reduced crude oil imports, the Soviet Union providing 30\% (i.e., $1.0 \mathrm{MMBD}$ ) of total refined product imports. More Soviet refined product imports to the U.S. will occur as a result of (1) increased crude oil production in Latin America and Africa that, to a large extent, will satisfy their own demand and (2) reduction in the Soviet refined product exports demand in other regions due to either more refinery activities (e.g., Eastern Europe and Western Europe) or less refined product exports (e.g., the Far East and Canada).

Uncertainties in future Soviet and Eastern Europe petroleum markets considered here in sensitivity analyses of the BAU scenario indicate that the BAU level (i.e., 49\%) of total net U.S. petroleum imports will remain unchanged. Crude oil availability from the Soviet Union will affect the distribution of U.S. crude oil and refined product imports. A higher level (i.e., 52\%) of total U.S. petroleum imports is forecasted if its crude oil production declines by $6.5 \%$ from the BAU level of 9.3 MMBD. The U.S. will import more crude oils than refined products from the Soviet Union; the reverse is true in the case of Canada. A maximum level of Soviet petroleum imports coming to the U.S. and Canada will be 1.05 MMBD and 1.2 MMBD, respectively. A consumption level $25 \%$ higher than the BAU scenario in the Soviet Union and Eastern Europe will be satisfied by the increase in refined product imports, financed by increased Soviet crude oil exports. On the other hand, a maximum amount of 4.65 MMBD of net Soviet petroleum exports could be available if consumption in the Soviet Union and Eastern Europe decreases by 10\%, compared with the BAU scenario level. Speculation about the Soviet Union becoming a net petroleum importer if the current crude oil production decline trend continues was observed in our analysis. We observed no net Soviet petroleum imports under the level of its crude oil production enough to meet its demand. Under that case, because of mismatch between the mix of refinery output and its refined products demand, refined products importation occured at the expense of refined product exports provided from crude oil imports. The assumption of no further deterioration of existing refining capacities made under that case may not be realistic in the future.

In summary, democratization of the Soviet Union and Eastern Europe will cause a few interesting world oil patterns in the year 2000. The U.S. and Canada will receive some portion of their iotal petroleum imports from the Soviet Union and Eastern Europe. However, the Middle East will continue to play the dominant role of petroleum supplier, as great uncertainties remain about future supplies from the Soviet Union. Easterr: Europe will face financial problems as more than $50 \%$ of its crude oil imports are forecasted to be coming from the Middle East.

For the Navy, vulnerability to disruptions in Middle East petroleum supply will continue to be an issue of concern until the current downward trend of the Soviet crude oil production improves. However, a significantly higher level of imports from the Soviet Union, and Eastern Europe may reduce the Navy's dependency on Middle East supplies. 


\section{REFERENCES}

Ashby, A. B. and D. A. Dreyfus (1990), The Global Outlook for Service Sector Energy Requirements, (GOSSER II), second update, Gas Research Institute, Washington, D.C., July.

Buck, P. B., et al. (1973), Supply and Distribution of POL to Tactical Forces, (U), WSEG Report 204, Institute for Defense Analyses, Systems Evaluation Division, Arlington, Virginia.

Cutler, T. (1986), "The Role of Petroleum in Wartime," Petroleum Economist, 53(4), p.137-142, April.

DACVA (Decision Analysis Corporation of Virginia) (1989), The Oil Trade Model (OTM), Draft Documentation, Vienna, Virginia, October.

Das, S., et al. (1988), Navy Mobility Fuels Forecasting System, Phase IV Report, ORNL-6517, Oak Ridge National Laboratory, Oak Ridge, Tennessee, September.

Das, S., et al. (1990), "Oil Markets Under Political and Military Stress," Energy Economics, 2(3), p.204-210, July.

DOE (U.S. Department of Energy) (1990), National Energy Strategy: Powerful Ideas for America, 1st Ed. 1991/1992, Washington, D.C.

Eastern Bloc Research, Ltd. (1991), "Soviet and East European Energy Databook," D. C. Wilson, ed., Newton Kyme, Tadcaster, North Yorkshire, United Kingdom.

EIA (Energy Information Administration) (1989), Washington, D.C., U.S. Department of Energy, International Energy Outlook 1989, DOE/EIA-0484(89), March.

EIA (Energy Information Administration) (1990a), Washington, D.C., U.S. Department of Energy, International Energy Outlook 1990 DOE/EIA-0484(90), March.

EIA (Energy Information Administration) (1991a), Washington, D.C., U.S. Department of Energy, International Energy Annual 1989, DOE/EIA-0219(89), February.

EIA (Energy Information Administration) (1991c), Washington, D.C., U.S. Department of Energy, International Petroleum Statistics Report 1991, DOE/EIA-0520(91/2), February.

EIA (Energy Information Administration) (1991b), Washington, D.C., U.S. Department of Energy, Performance Profiles of Major Energy Producers 1989, DOE/EIA-0206(89), January.

EIA (Energy Information Administration) (1991b), Washington, D.C., U.S. Department of Energy, Petroleum Supply Annual 1989: Volume 1, DOE/EIA-0340(89)/1, May.

Fridley, D. (1990), "China's Oil Industry: A Decade in Review and Challenges Ahead," a report of the China Energy Study, Energy Program, East-West Center, Honolulu, August. 
Gaffney, Cline \& Associates (1989), Prospects for and Orjportunities in the East European and USSR Energy Markets to 2005, Hampshire, United Kingdom.

Hadder, G. R., et al. (1987), Navy Mobility Fuels Forecasting System, Phase III Report, ORNL-6400, Oak Ridge National Laboratory, Oak Ridge, Tennessee, August.

Hadder, G. R., and R. M. Davis (1991), Navy Mobility Fuels Forecasting System Report: Navy Fuel Production In The Year 2000, ORNL-6684, Oak Ridge National Laboratory, Oak Ridge, Tennessee, November.

International Monetary Fund, et al. (1990), The Economy of the USSR: A Study Undertaken in Response to a Request by the Houston Summit: Summary and Recommendations, Washington, D.C.

Korchemkin, M. B. (1989), Energy Aspects of Perestroika, Paper No. 89.2, Center for International Energy Studies, Erasmus University, Rotterdam, April.

Lee, R., S. Das, and P. N. Leiby (1991), Navy Mobility Fuels Forecasting System, Phase VI Report, ORNL-6636, Oak Ridge National Laboratory, Oak Ridge, Tennessee, January.

Leiby, P. N., and T. J. Teisberg (1991), Potential Economic Benefits of Alternative Fuel Use: An Interim Report on Market Analysis Utilizing the Alternative Fuels Trade Model, ORNL6676, Oak Ridge National Laboratory, Oak Ridge, Tennessea. (to be published).

Lippman, T. W., and M. Potts (1991), "Falling Soviet Output May Cause Global Crunch," The Washington Post.

Movit, C. (1991), "East Europe's Energy Trade Takes New Shape," Oil \& Gas Journal, 89(22), p.57-64, June.

Petroleum Economist (1991), "Soviet Union: Oil Exports Shrink," 58(1), p.17, January.

Sagers, M. J., and M. B. Green (1986), "The Transportation of Refined Petroleum Products and the Efficient Location of Refineries in the USSR," Applied Geography, 6(4), p.339-357.

Sieff, M. (1991), "Soviet Oilfield Foul-Ups Could Force Imports," The Washington Times, February 20.

Tahmassebi, C. (1991), "Environmental Regulations and the U.S. Refining Industry," paper presented at the 14th International Association for Energy Economics (IAEE) Conference, July 8-10, Honolulu.

Turhollow, A. F., T. R. Curlee, and S. Das (1987), Documentation of the Petroleum Allocation (PAL) Model ORNL/CF-87/19, Oak Ridge National Laboratory, Oak Ridge, Tennessee, March.

Verleger, P. K., Jr. (1990), "Understanding the 1990 Oil Crisis," The Energy Journal, 11(4), p.15-33.

Vervalin, C. (1990), "World Petroleum Market, 1990-95 Forecast in New E-WC Report," Hydrocarbon Processing, 69(8), p.23, August. 


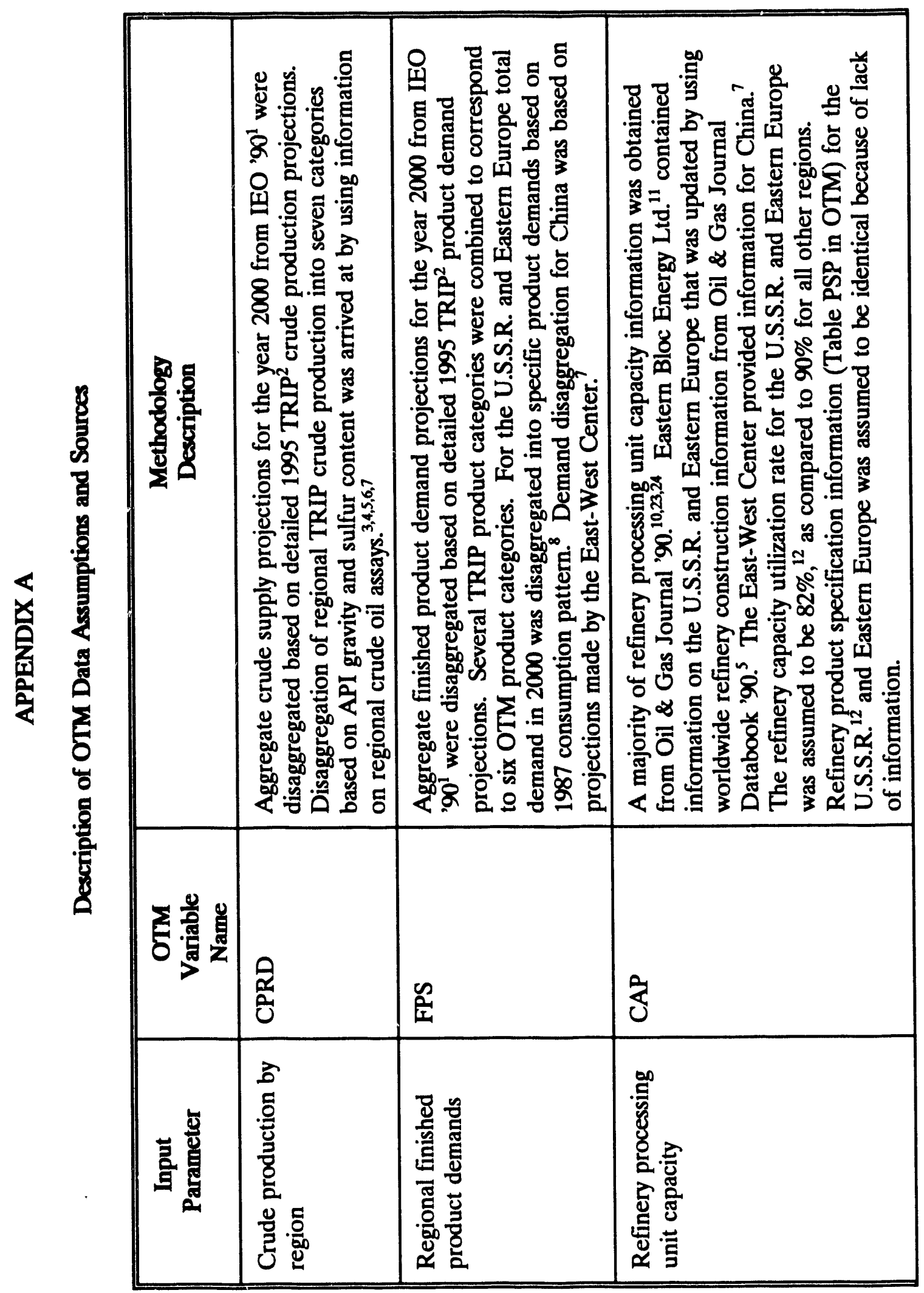




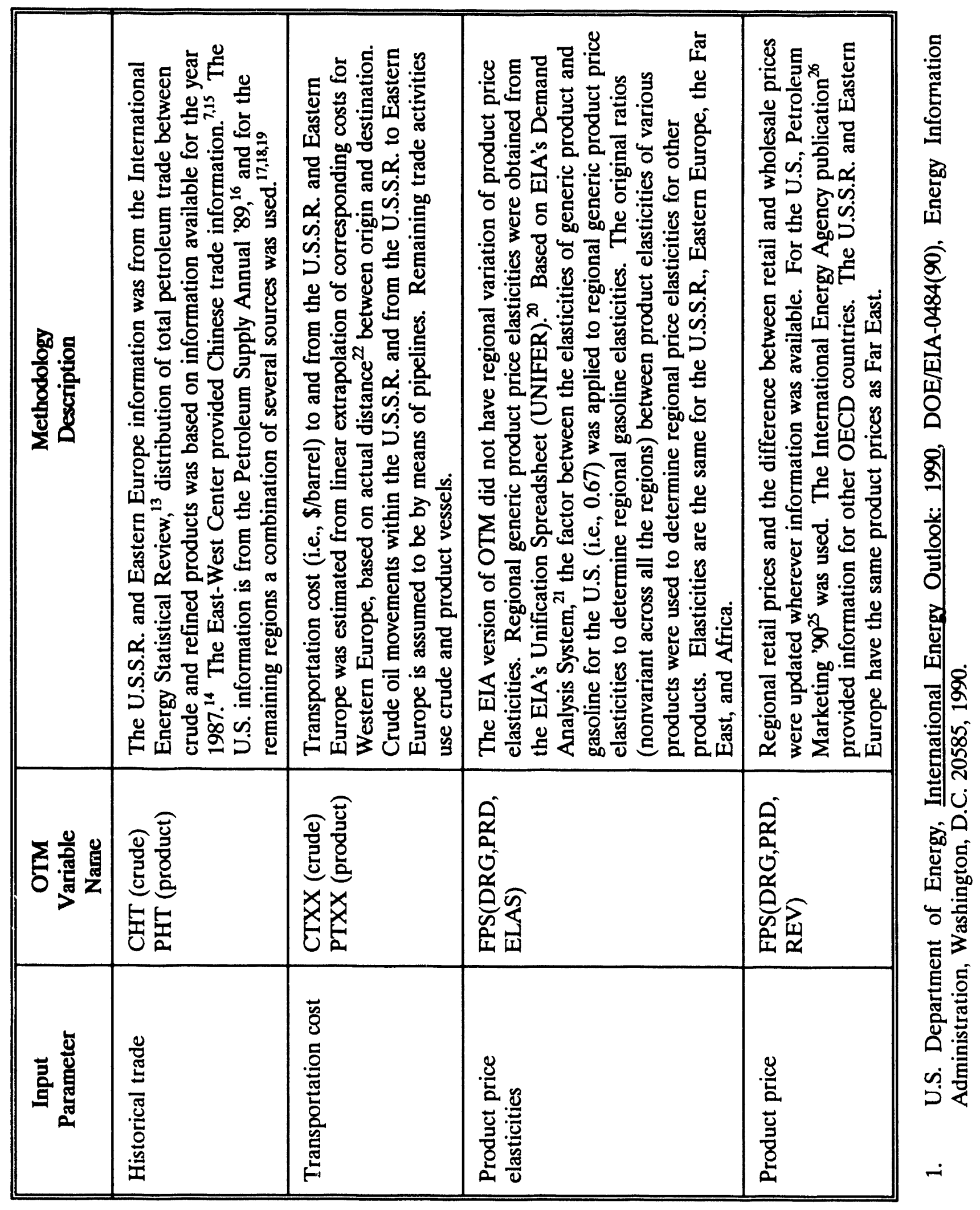




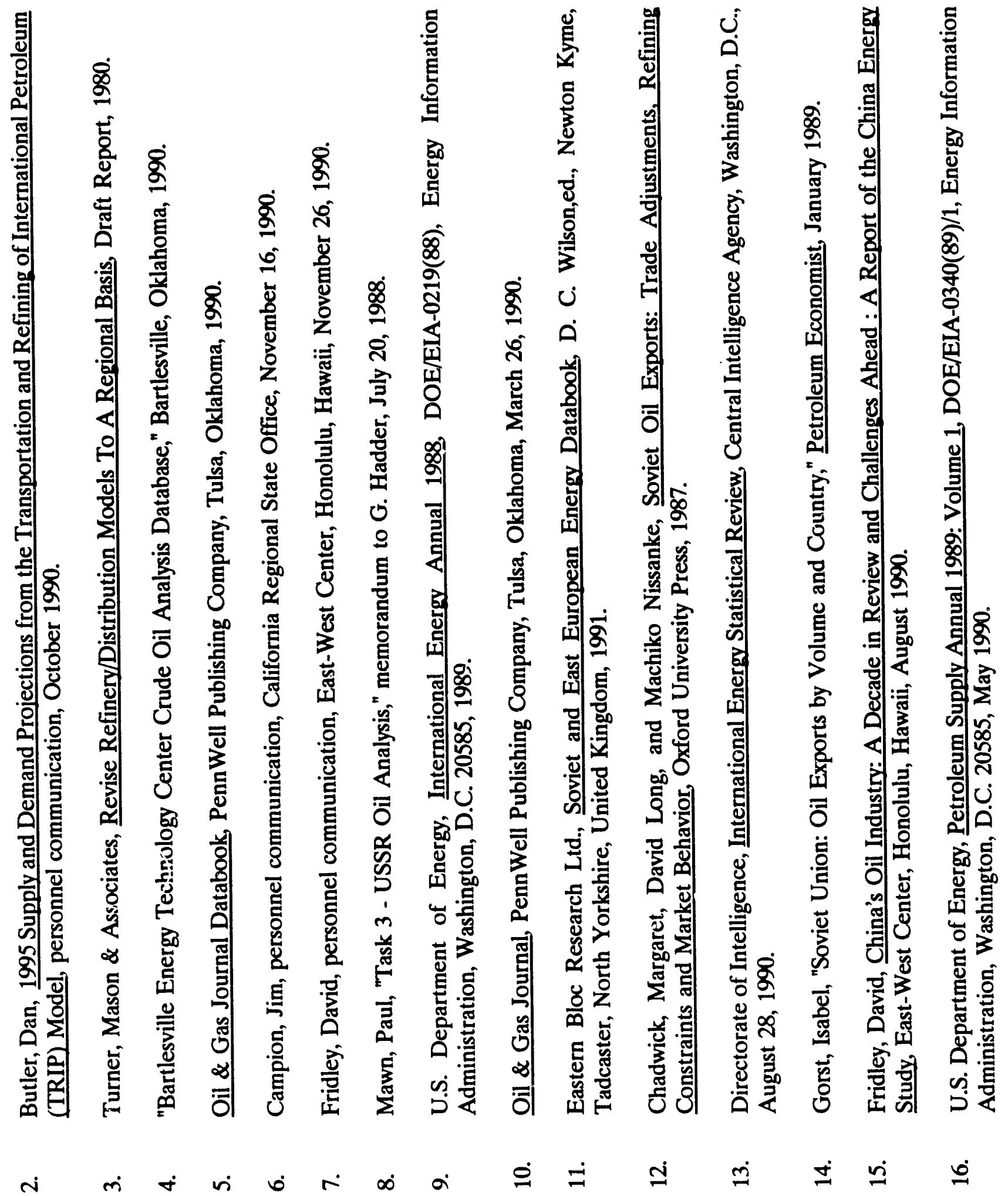




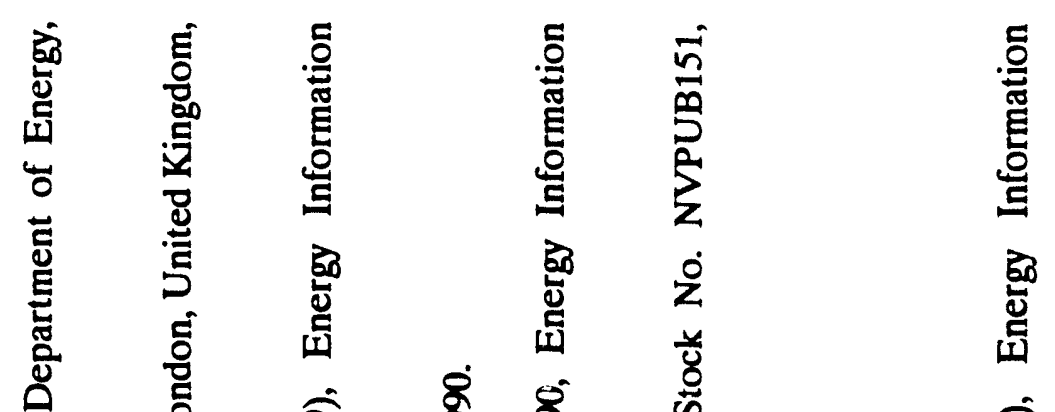

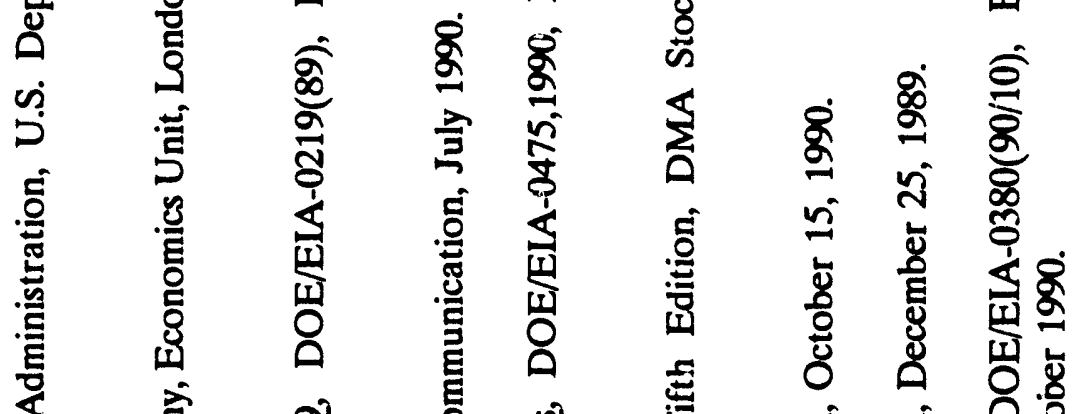

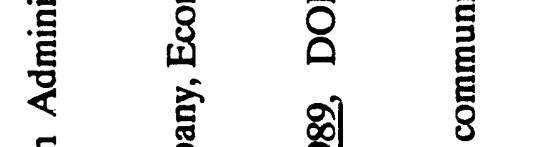

\%

.

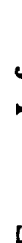
(1)

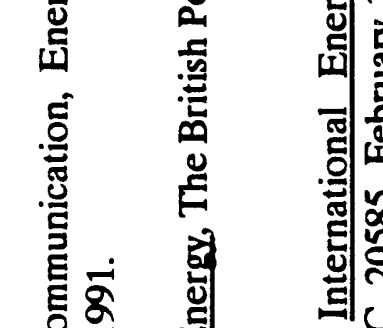

昰总

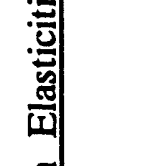

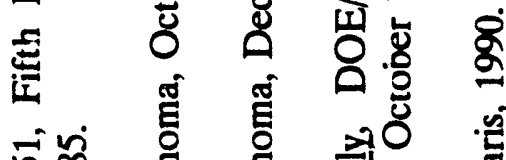

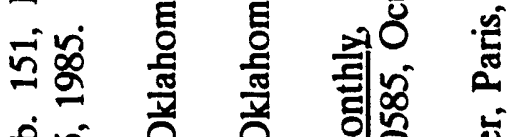

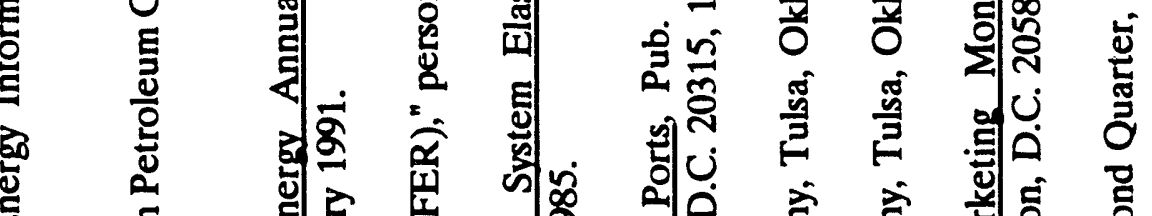

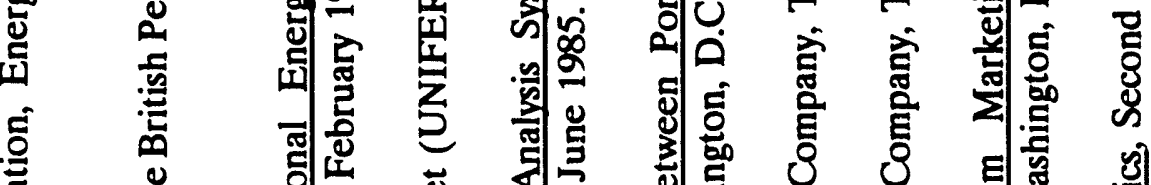

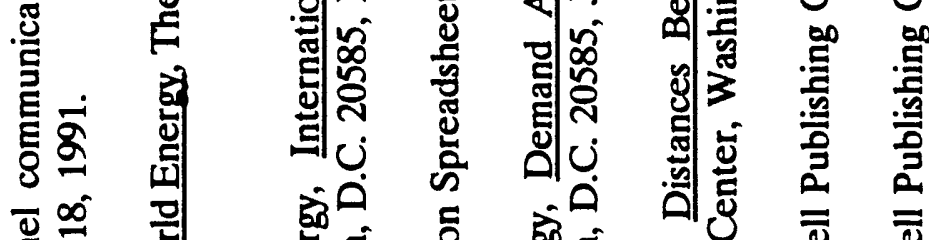

दूं

总究

बं

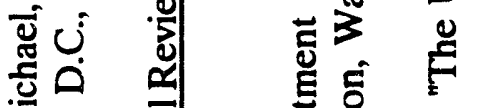

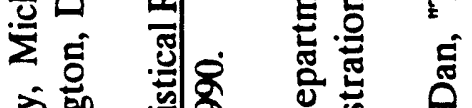

㐫.

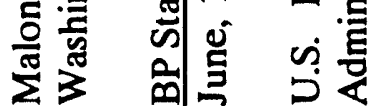

过它

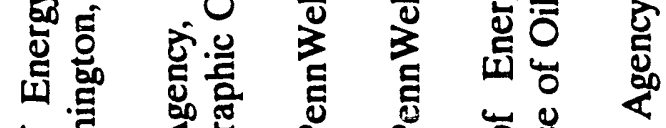

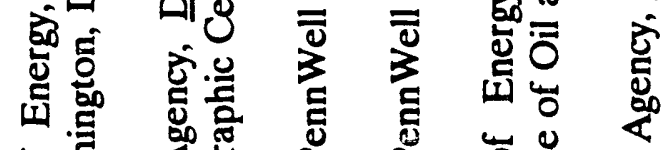

पे

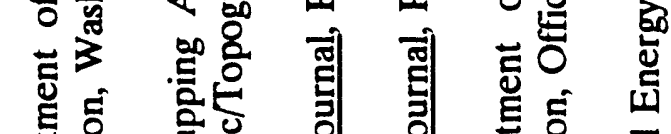

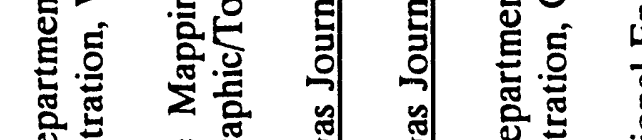

苍苟

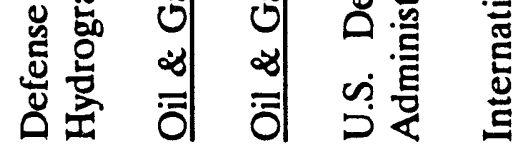

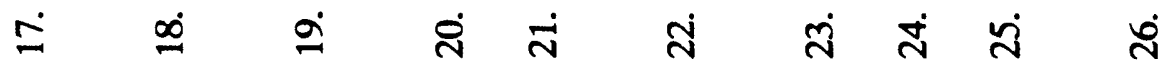


NAVY MOBILITY FUELS FOREC ASTING SYSTEM REPORT:

WORLD PETROLEUM TRADE FOR ECASTS FOR THE YEAR 2000

\section{APPENDIX B \\ WORLD PETROLEUM TRADE FLOWS IN THE YEAR 20007}

${ }^{7}$ Results for crude and refined products are provided separately here and represented as changes from those corresponding flows in 1989 and/or the year 2000 BAU scenario. Changes (i.e., bottom table in the page) when added to the actual flows (i.e., top table in the page) from which changes are calculated, give the actual flows for a particular scenario. For the LOIL scenario only, comparisons of world trade flows have been provided against flows in 1989 as well as the year 2000 BAU scenario. 


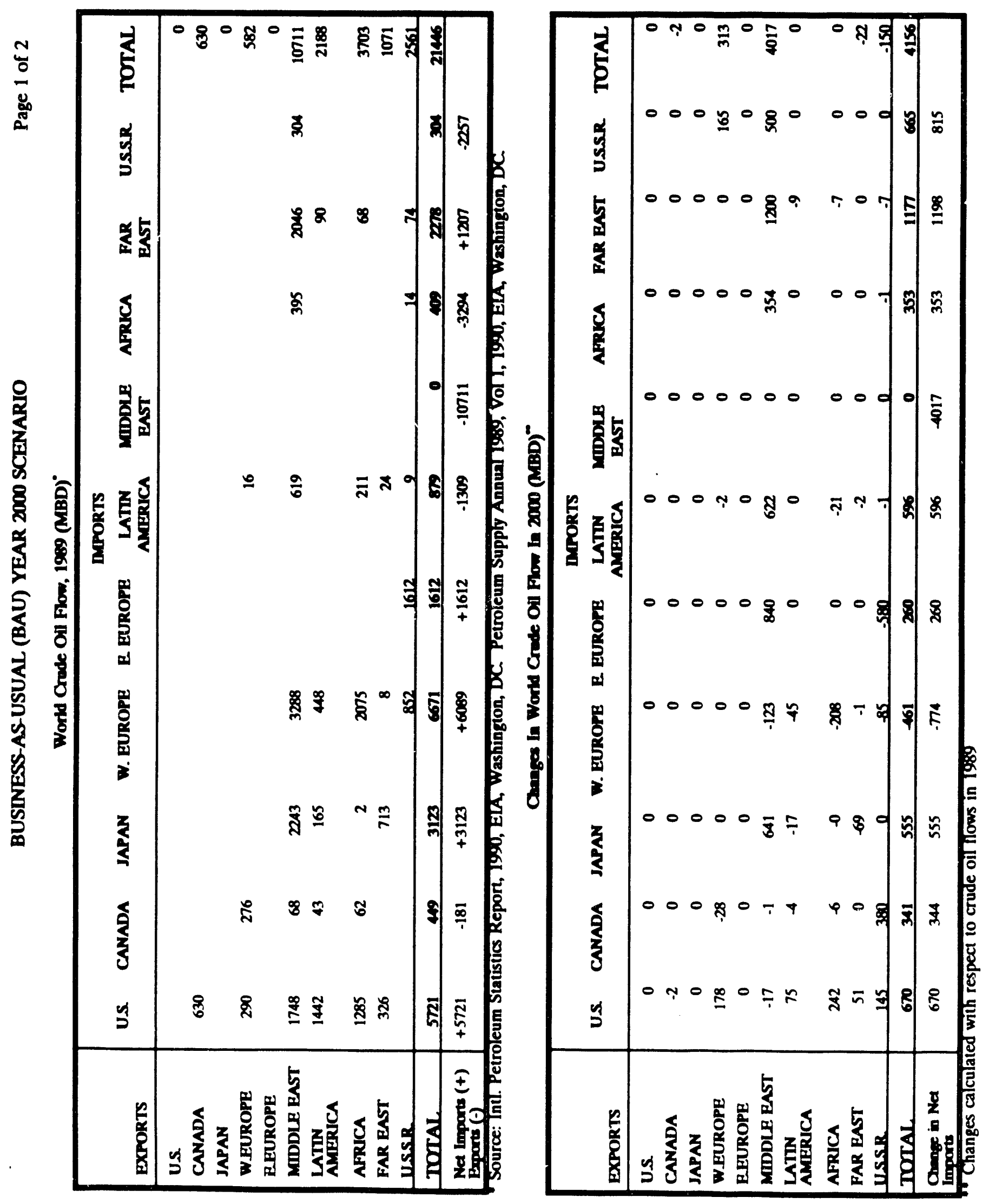



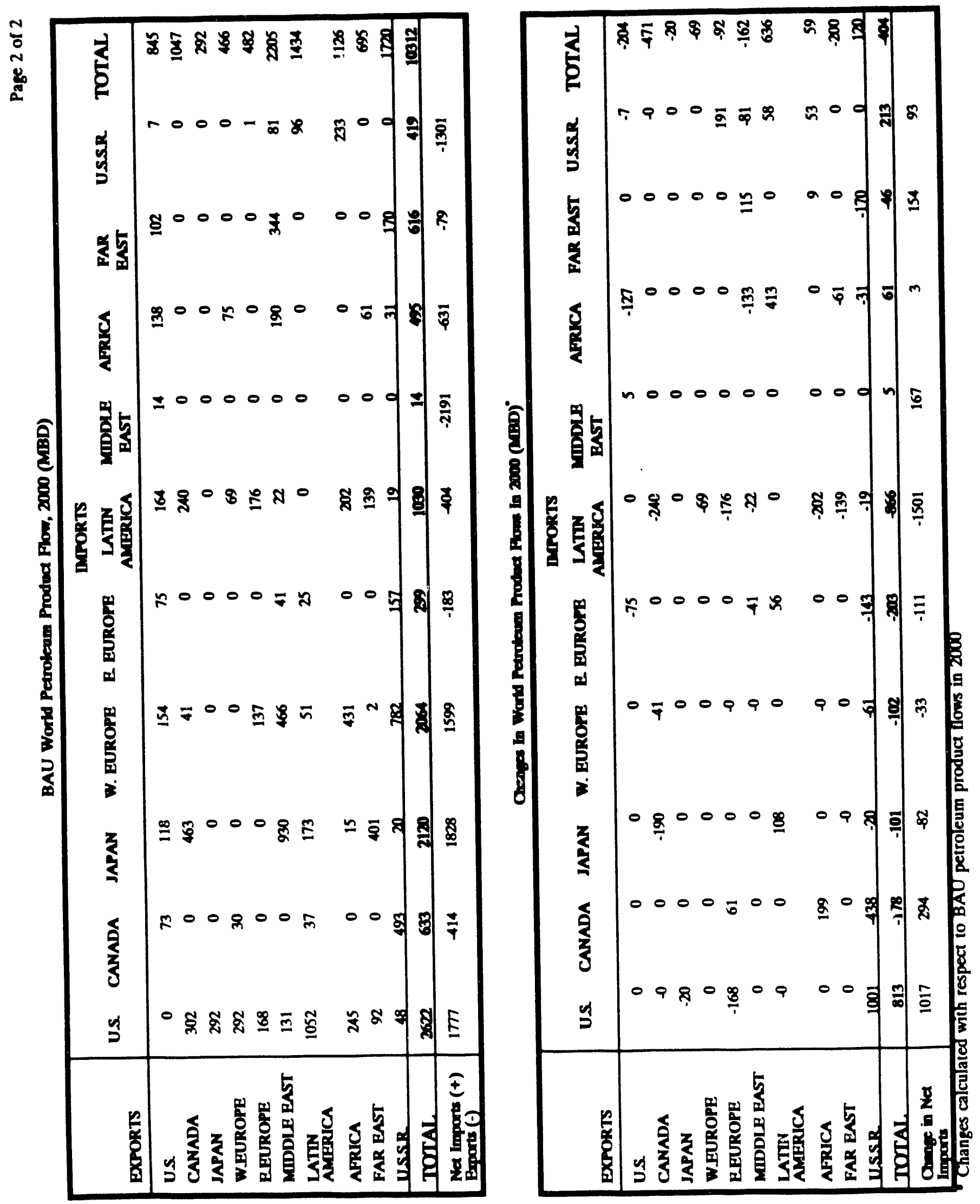


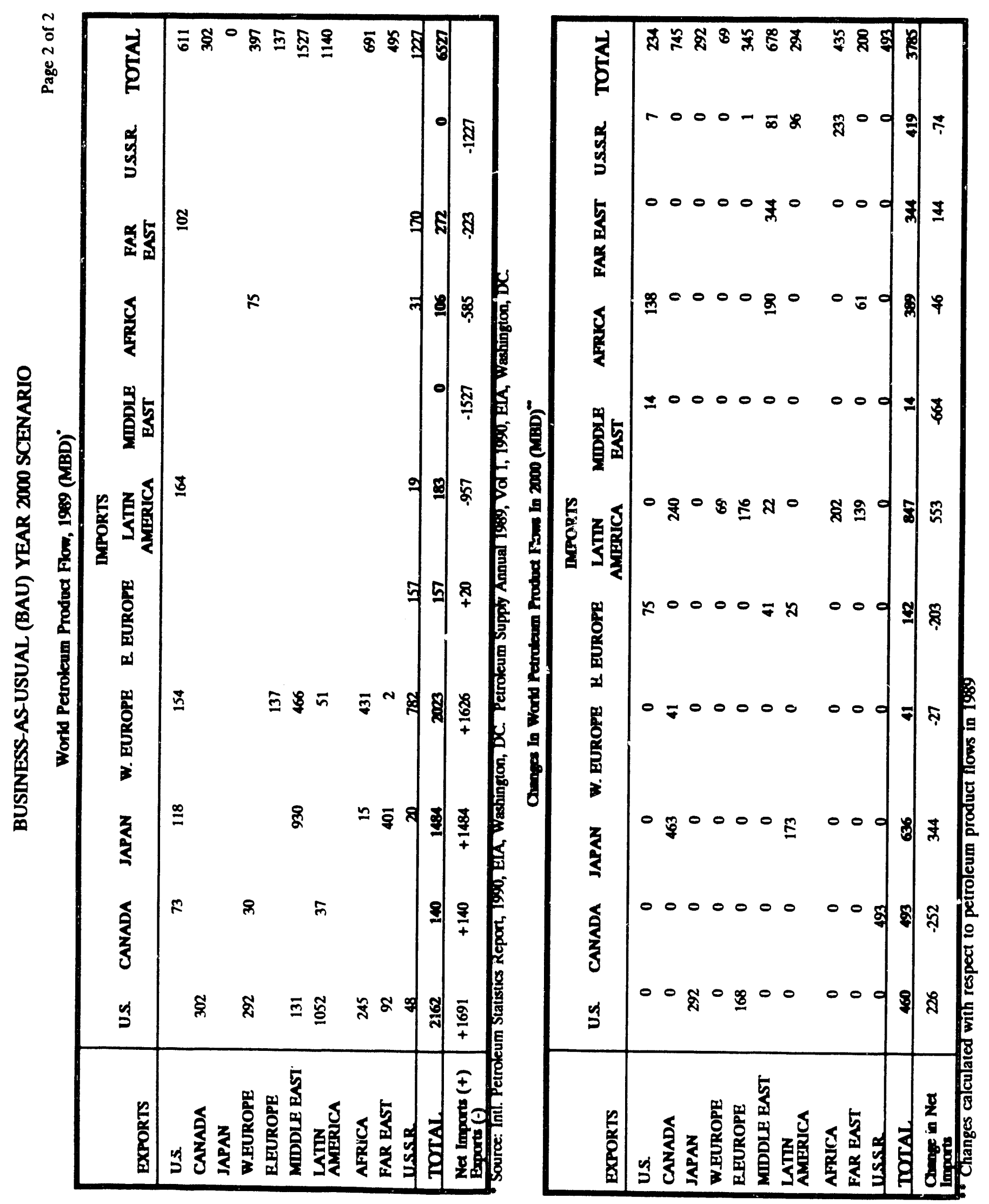




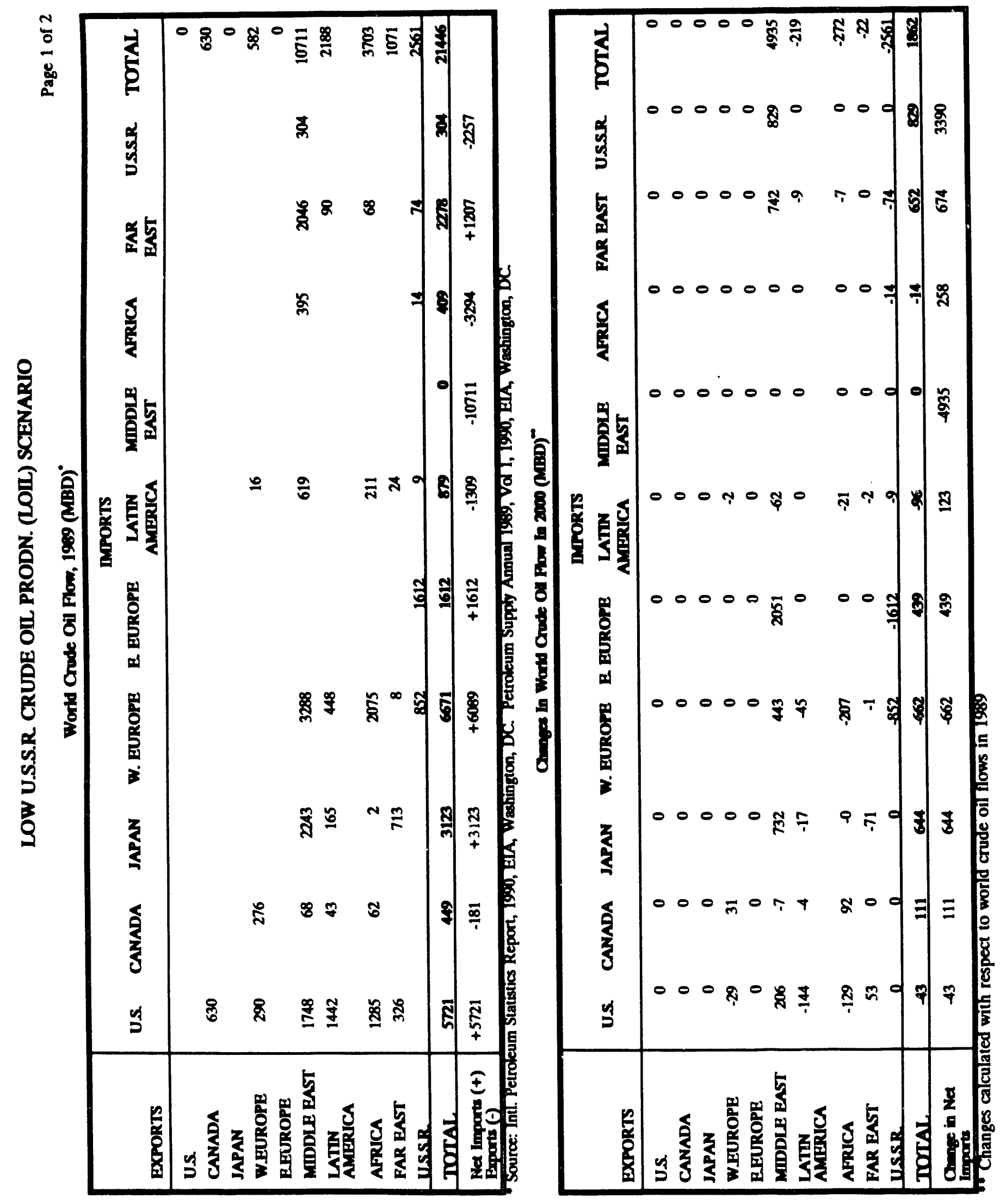




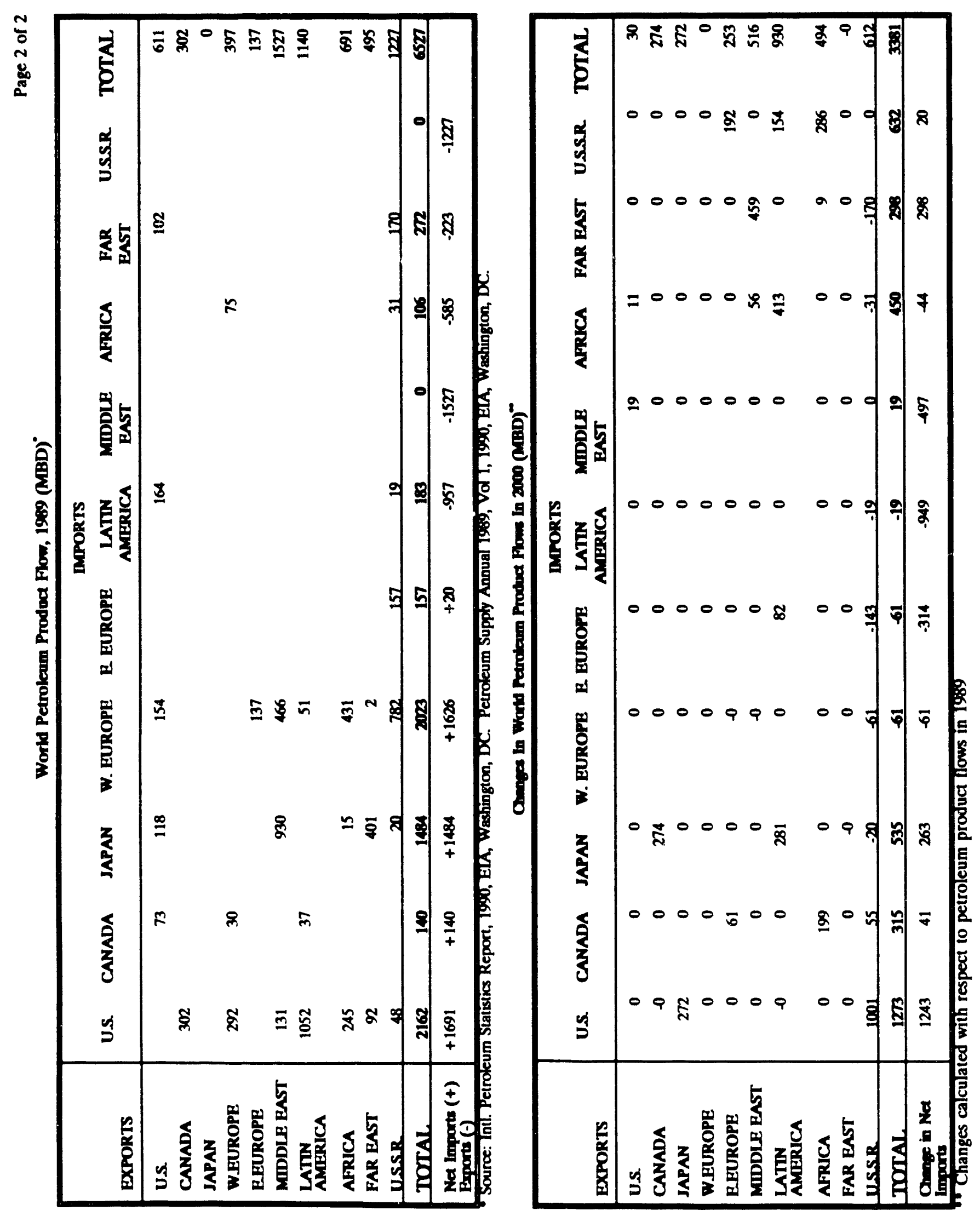



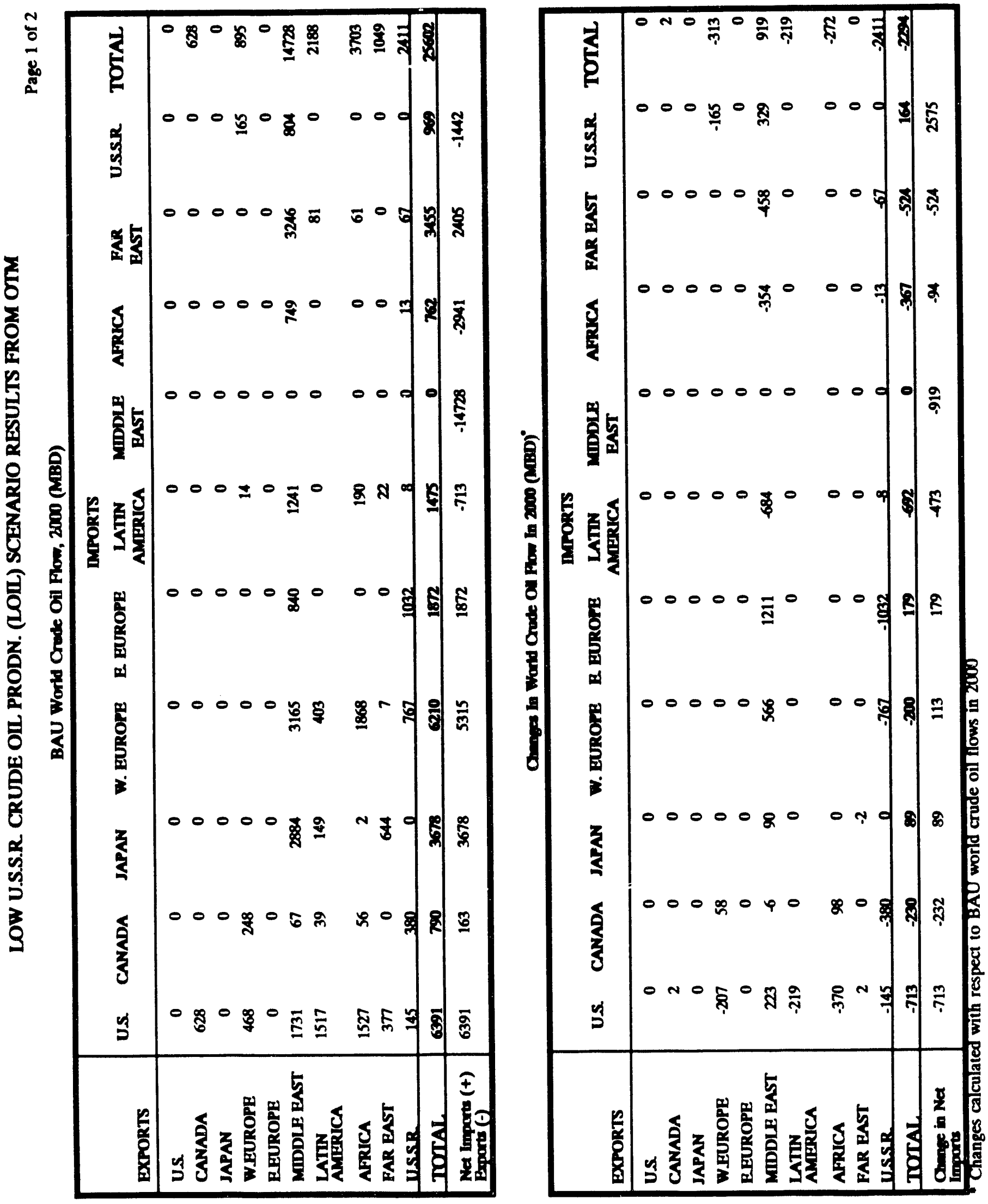


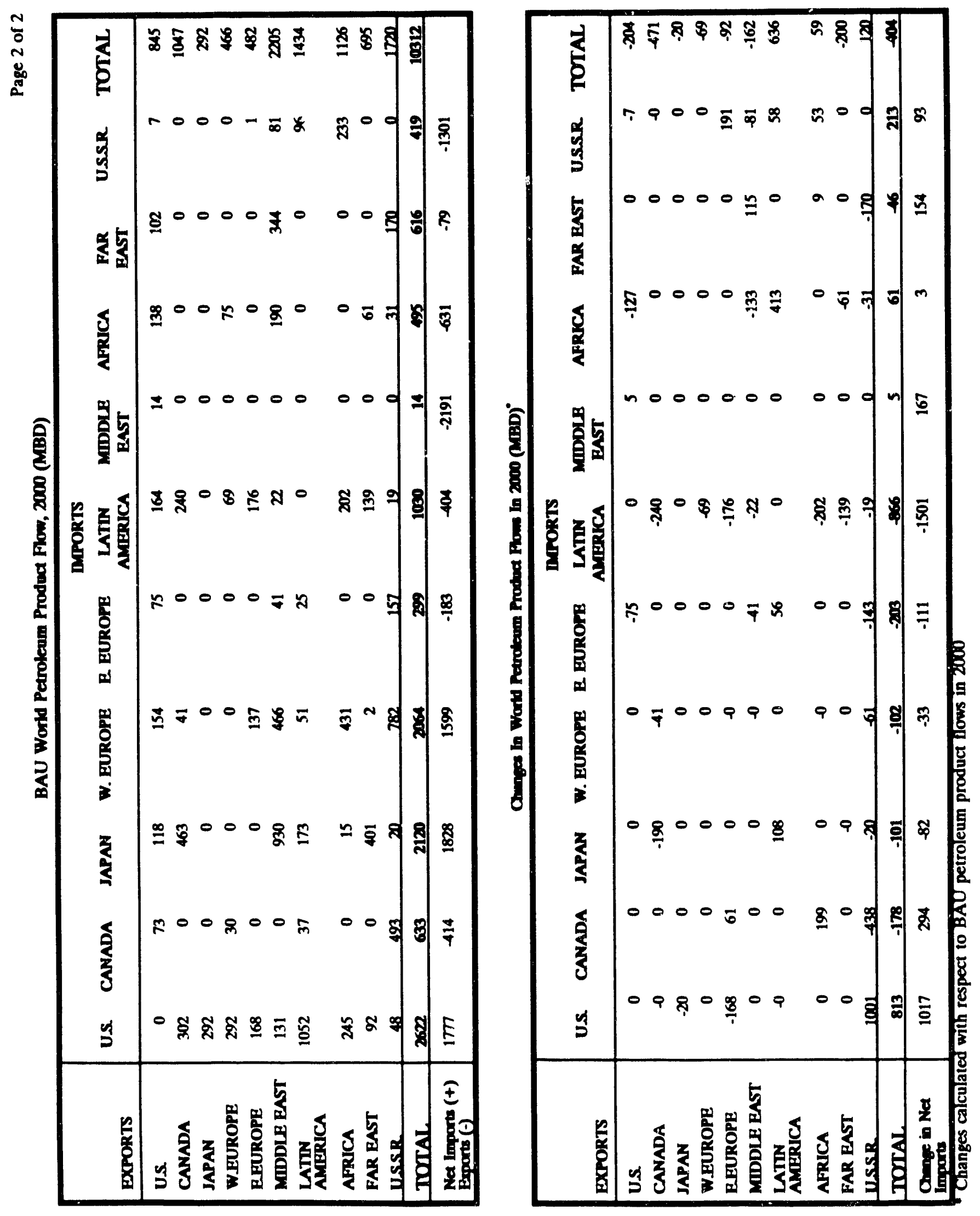


NAVY MOBUITY FUELS FORECASTING SYSTEM REPORT:

WORLD PETROLEUM TRADE FORECASTS FOR THE YEAR 2000

APPENDIX C

WORLD REFINERY OUTPUT IN THE YEAR 2000

39 


\section{SUMMARY OF REFINED PRODUCT OUTPUT IN OTM REGIONS UNDER VARIOUS SCENARIOS FOR 2000}

\begin{tabular}{|c|c|c|c|c|c|c|c|c|c|c|}
\hline \multirow[b]{3}{*}{ Product } & \multicolumn{2}{|c|}{ U.S. PADD 1} & \multicolumn{2}{|c|}{ U.S. PADD $2 \& 4$} & \multicolumn{2}{|c|}{ U.S. PADD 3} & \multicolumn{2}{|c|}{ U.S. PADD 5} & \multicolumn{2}{|c|}{ U.S. TOTAL } \\
\hline & \multicolumn{2}{|c|}{ SCENARIO } & \multicolumn{2}{|c|}{ SCENARIO } & \multicolumn{2}{|c|}{ SCENARIO } & \multicolumn{2}{|c|}{ SCENARIO } & \multicolumn{2}{|c|}{ SCENARIO } \\
\hline & BAU & LOIL & BAU & LOIL & BAU & LOIL & BAU & LOIL & BAU & LOIL \\
\hline LPG Product & 167 & 180 & 840 & 768 & 1645 & 1686 & 279 & 272 & 2,933 & 2,907 \\
\hline $\begin{array}{l}\text { Gasoline } \\
\text { (Hi-Octane) }\end{array}$ & 554 & 538 & 1977 & 1731 & 2807 & 2877 & 992 & 990 & 6,332 & 6,138 \\
\hline $\begin{array}{l}\text { Gasoline } \\
\text { (Lo-Octane) }\end{array}$ & 0 & 0 & $\mathbf{0}$ & 0 & $\mathbf{0}$ & $\mathbf{0}$ & $\mathbf{0}$ & $\mathbf{0}$ & $\mathbf{0}$ & $\mathbf{0}$ \\
\hline Naphthas & $\mathbf{0}$ & 6 & $\mathbf{0}$ & $\mathbf{0}$ & $\mathbf{0}$ & $\mathbf{0}$ & $\mathbf{0}$ & $\mathbf{0}$ & $\mathbf{0}$ & 6 \\
\hline Middle Distillates & 374 & 391 & 1050 & 1018 & 2308 & 1890 & 813 & 819 & 4,547 & 4,120 \\
\hline $\begin{array}{l}\text { Residual Fuel Oil - } \\
\text { Low Sulfur }\end{array}$ & 233 & 74 & 91 & 39 & 457 & 338 & 141 & 154 & 923 & 606 \\
\hline $\begin{array}{l}\text { Residual Fuel Oil - } \\
\text { High Sulfur }\end{array}$ & 42 & 125 & 34 & 147 & 522 & 281 & 290 & 297 & 890 & 852 \\
\hline Coke Product & 44 & 44 & 51 & 51 & 44 & 44 & 158 & 136 & 299 & 277 \\
\hline TOTAL & 1,417 & 1,361 & 4,046 & 3,756 & 7,786 & 7,119 & 2,675 & 2,671 & 15,925 & 14,908 \\
\hline
\end{tabular}

Note: 1. Units are thousand barrels per day (MBD)

Scenario Descriptions

BAU: Business-As-Usual Scenario

LOIL: Low USSR Crude Oil Production Scenario

Region Definitions

U.S. PADD1 Connecticut, Delaware, District of Columbia, Florida, Georgia, Maine, Maryland, Massachusetts, New Hampshire, New Jersey, New York, North Carolina, Pennsylvania, Rhode Island, South Carolina, Vermont, Virginia and West Virginia.

U.S. PADD2\&4 Colorado, Idaho, Illinois, Indiana, Iuwa, Kansas, Kentucky, Michigan, Minnesota, Missouri, Montana, Nebraska, North Dakota, Ohio, Oklahoma, South Dakota, Tennessee, Utah, Wisconsin, and Wyoming.

U.S. PADD3 Alabama, Arkansas, Louisiana, Mississippi, New Mexico and Texas.

U.S. PADD5 Alaska, Arizona; California, Hawaii, Nevada, Oregon, and Washington. 


\section{SUMMARY OF REFINED PRODUCT OUTPUT IN OTM REGIONS UNDER VARIOUS SCENARIOS FOR 2000}

\begin{tabular}{|c|c|c|c|c|c|c|c|c|c|c|}
\hline \multirow[b]{4}{*}{ PRODUCT } & \multicolumn{10}{|c|}{ REGION } \\
\hline & \multicolumn{2}{|c|}{ CANADA } & \multicolumn{2}{|c|}{$\begin{array}{l}\text { WESTERN } \\
\text { EUROPE }\end{array}$} & \multicolumn{2}{|c|}{$\begin{array}{l}\text { LATIN } \\
\text { AMERICA }\end{array}$} & \multicolumn{2}{|c|}{ AFRICA } & \multicolumn{2}{|c|}{ FAR EAST } \\
\hline & \multicolumn{2}{|c|}{ SCENARIO } & \multicolumn{2}{|c|}{ SCENARIO } & \multicolumn{2}{|c|}{ SCENARIO } & \multicolumn{2}{|c|}{ SCENARIO } & \multicolumn{2}{|c|}{ SCENARIO } \\
\hline & BAU & LOIL & BAU & LOIL & BAU & LOIL & BAU & LOIL & BAU & LOIL \\
\hline LPG Produz: & 404 & 429 & 1161 & 1169 & 984 & 1108 & 385 & 416 & 820 & 781 \\
\hline Gasoline (Hi-Octane) & 462 & 646 & 2722 & 2716 & 184 & 102 & 114 & 49 & 592 & 586 \\
\hline $\begin{array}{l}\text { Gasoline } \\
\text { (Lo-Octane) }\end{array}$ & $\mathbf{0}$ & $\mathbf{0}$ & $\mathbf{0}$ & 0 & 1339 & 1534 & 382 & 531 & 1364 & 1303 \\
\hline Naphthas & 77 & 51 & 285 & 318 & 337 & 426 & 364 & 365 & 622 & 439 \\
\hline Middle Distillates & 585 & 425 & 2982 & 3113 & 1444 & 1628 & 867 & 889 & 2107 & 2261 \\
\hline $\begin{array}{l}\text { Residual Fuel Oil - } \\
\text { Low Sulfur }\end{array}$ & 342 & 238 & 2065 & 1723 & 606 & 783 & 635 & 757 & 1572 & 1564 \\
\hline $\begin{array}{l}\text { Residual Fuel Oil - } \\
\text { High Sulfur }\end{array}$ & 404 & 175 & 961 & 1171 & 1394 & 2210 & 396 & 130 & 1166 & 1171 \\
\hline Coke Product & 0 & 14 & 56 & 56 & 74 & 74 & 0 & 3 & 45 & 29 \\
\hline TOTAL & 2,276 & 1,982 & 10,235 & 10,269 & 6,366 & 7,868 & 3,146 & 3,143 & 8,291 & 8,137 \\
\hline
\end{tabular}

Note: 1. Units are thousand barrels per day (MBD)

Scenario Descriptions

BAU: Business-As-Usual Scenario

LOIL: LOw USSR Crude Oil Production Scenario

Region Definitions

LATIN AMERICA Argentina, Bolivia, Brazil, Colombia, Ecuador, Mexico, Tobago and Trinidad, and Venezuela.

AFRICA

Argentina, Bolivia, Brazil, Colombia, Ecuador, Mexico,
Algeria, Cameroons, Egypt, Libya, Nigeria, and Tunisia.

FAR EAST

Australia, Brunei, China, India, Indonesia, Malaysia, New Zealand, Pakistan, Taiwan, and Thailand. 


\section{SUMMARY OF REFINED PRODUCT OUTPUT IN OTM REGIONS UNDER VARIOUS SCENARIOS FOR 2000}

\begin{tabular}{|c|c|c|c|c|c|c|c|c|}
\hline \multirow[b]{4}{*}{ PRODUCT } & \multicolumn{8}{|c|}{ REGION } \\
\hline & \multicolumn{2}{|c|}{ MIDDLE EAST } & \multicolumn{2}{|c|}{ JAPAN } & \multicolumn{2}{|c|}{$\begin{array}{l}\text { EASTERN } \\
\text { EUROPE }\end{array}$} & \multicolumn{2}{|c|}{ U.S.S.R. } \\
\hline & \multicolumn{2}{|c|}{ SCENARIO } & \multicolumn{2}{|c|}{ SCENARIO } & \multicolumn{2}{|c|}{ SCENARIO } & \multicolumn{2}{|c|}{ SCENARIO } \\
\hline & BAU & LOIL & BAU & LOIL & BAU & LOIL & BAU & LOIL \\
\hline LPG Product & 781 & 736 & 320 & 320 & 136 & 153 & 758 & 661 \\
\hline $\begin{array}{l}\text { Gasoline (Hi- } \\
\text { Octane) }\end{array}$ & 52 & 156 & 734 & 734 & 135 & 115 & 943 & 1028 \\
\hline $\begin{array}{l}\text { Gasoline (Lo- } \\
\text { Octane) }\end{array}$ & 594 & 508 & $\mathbf{0}$ & $\mathbf{0}$ & 458 & 532 & 1503 & 1232 \\
\hline Naphthas & 523 & 503 & 339 & 369 & $\mathbf{0}$ & 70 & 0 & $\hat{\mathrm{v}}$ \\
\hline Middle Distillates & 1439 & 1353 & 1140 & 1118 & 658 & 793 & 2396 & 2465 \\
\hline $\begin{array}{l}\text { Residual Fuel Oil - } \\
\text { Low Sulfur }\end{array}$ & 488 & 478 & 766 & 877 & 184 & 258 & 1042 & 1341 \\
\hline $\begin{array}{l}\text { Residual Fuel Oil - } \\
\text { High Sulfur }\end{array}$ & 1163 & 1144 & 252 & 214 & 626 & 383 & 2078 & 1879 \\
\hline \multirow[t]{2}{*}{ Coke Product } & 108 & 103 & 4 & 4 & $\mathbf{0}$ & 3 & 74 & 97 \\
\hline & 5,151 & 4,984 & 3,556 & 3,638 & 2,200 & 2,311 & 8,797 & 8,704 \\
\hline
\end{tabular}

Note: 1. Units are thousand barrels per day (MBD)

Scenario Descriptions

BAU: Business-As-Usual Scenario

LOIL: Low USSR Crude Oil Production Scenario

Region Definitions

MIDDLE EAST

Bahrain, Iran, Kuwait, Oman, Qatar, Saudi Arabia, and UAE.

EASTERN EUROPE

Bulgaria, Czechoslovakia, East Germany, Hungary, Poland, and Romania. 
ORNL-6683

\section{INTERNAL DISTRIBUTION}
1. T. Ault
2. M. S. Bronzini
3. D. P. Bivens
4. B. L. Bush
5. J. B. Cannon
6-10. S. Das
11. R. M. Davis
12. K. G. Gilley
13. P. S. Gillis
14. D. L. Greene
15. G. R. Hadder
16. G. Harrison
17. L. J. Hill
18. P. S. Hu
19. H. L. Hwang
20. N. Jett
21. C. R. Kerley

22. J. Kolb

23. M. A. Kuliasha

24. R. Lee

25. P. N. Leiby

26. M. MacDonald

27. V. C. Mei

28. W. R. Mixon

29. D. E. Reichle

30. R. N. Scogin

31. R. B. Shelton

32. J. E. Sorenson

33. P. D. Witcher

34. ORNL Patent Office

35. Central Research Library

36. Document Reference Section

37-39. Laboratory Records

40. Laboratory Records--RC

\section{EXTERNAL DISTRIBUTION}

41. B. G. Buchanan, Professor, Computer Science Department, University of Pittsburgh, 206 Mineral Industries Building, Pittsburgh, PA 15260

42. D. Butler, Energy Information Administration, U.S. Department of Energy Room 5A-139, 1000 Independence Avenue, S.W., Washington, DC 20585

43. M. Crandall, Director, Energy, Economics and Trade Division, GA-301/Forrestal Building, U.S. Department of Energy, Washington, DC 20585

44. J. J. Cuttica, Vice President, End Use Research and Development, Gas Research Institute, 8600 W. Bryn Mawr Avenue, Chicago, IL 60631

45. D. Dunbar, Private Consultant, 784 Columbia Avenue, Apt. 4E, New York, NY 10025

46. P. Farah, General Accounting Office, 441 G Street, NW, Washington, DC 20548

47. M. Galindo, Bruce Morgan Associates, 1010 N. Glebe Rd., Suite 500, Arlington, VA 22201

48. Y. Garcia, Idemitsu Apollo Corp., 50 Rockefeller Plaza, Rm. No. 1038, New York, NY 10020

49. C. Heath, Energy Information Administration, Department of Energy, EI-42, Forrestal Building, 1000 Independence Avenue, S.W., Washington, DC 20585 
50. J. Hinkle, Strategic Petroleum Reserve, Room 3G-024, 1000 Independence Avenue, S.W., Washington, DC 20585

51. A. Hirsch, Dr., Vice-President, Environmental Sciences, Midwest Research Institute, Washington, D.C. Office, 5109 Leesburg Pike, Suite 414, Falls Church, VA 22041

52. I. Kagan, Petroleum Industry Research Associates, 122 East 42nd Street, Rm 516, New York, NY 10168

53. C. Kilgore, Energy Information Administration, Department of Energy, Room 1Hö7, Forrestal Building, 1000 Independence Avenue, S.W., Washington, DC 20.585

54. J. Lawton, Bonner \& Moore Associates, 2727 Allen Parkway, Houston, TX 77019

55. S. Miller, Petroleum Intelligence Weekly, 575 Broadway, New York, NY 10012

56. D. E. Morrison, Professor of Sociology, Michigan State University, 201 Berkeley Hall, East Lansing, MI 48824-1111

57-61. C. J. Nowack, Naval Air Propulsion Center, Code PE33, P.O. Box 7176, Trenton, NJ 08628

62. R. L. Perrine, Professor of Engineering and Applied Sciences, Engineering I, Room 2066, 405 Hilgard Avenue, University of California, Los Angeles, CA 90024-1600

63. R. Pompa, Unocal Oil Co., 911 Wilshire Blvd., Rm 1224, Los Angeles, CA 90017

64-74. A. Roberts, Office of Naval Research, Navy Energy \& Natural Resources Office, Conde ONR-12E, 800 N. Quincy Street, Arlington, VA 22217-5000

75. A. Roehmer, U.S. Department of Energy, 1000 Independence Avenue, S.W., Room 4G-084, Washington, DC 20585

76. N. R. Sefer, Senior Research Engineer, Southwest Research Institute, Fuels and Lubricants Research Division, 6220 Culebra Road, P.O. Drawer 28510, San Antonio, TX 78284

77-86. R. Strucko, David Taylor Naval Ship Research and Development Center, Code 2759, Annapolis, MD 21402

87. M. Tallett, EnSys Energy and Systems, Inc., Rd. 7, Box 519, Flemington, NJ 08822

88. W. Vreatt, Naval Ordnance Station, Management Operations Group, Code 56C1, Indian Head, MD 20640

80. M. Williams, Professor, Department of Economics, Northern Illinois University, DeKalb, IL 60115 
90-99. OSTI, U.S. Department of Energy, P.O. Box 62, Oak Ridge, TN 37831

100. Office of Assistant Manager of Energy Research and Development, DOE/ORO, P.O. Box 2001, Oak Ridge, TN 37831-8600 

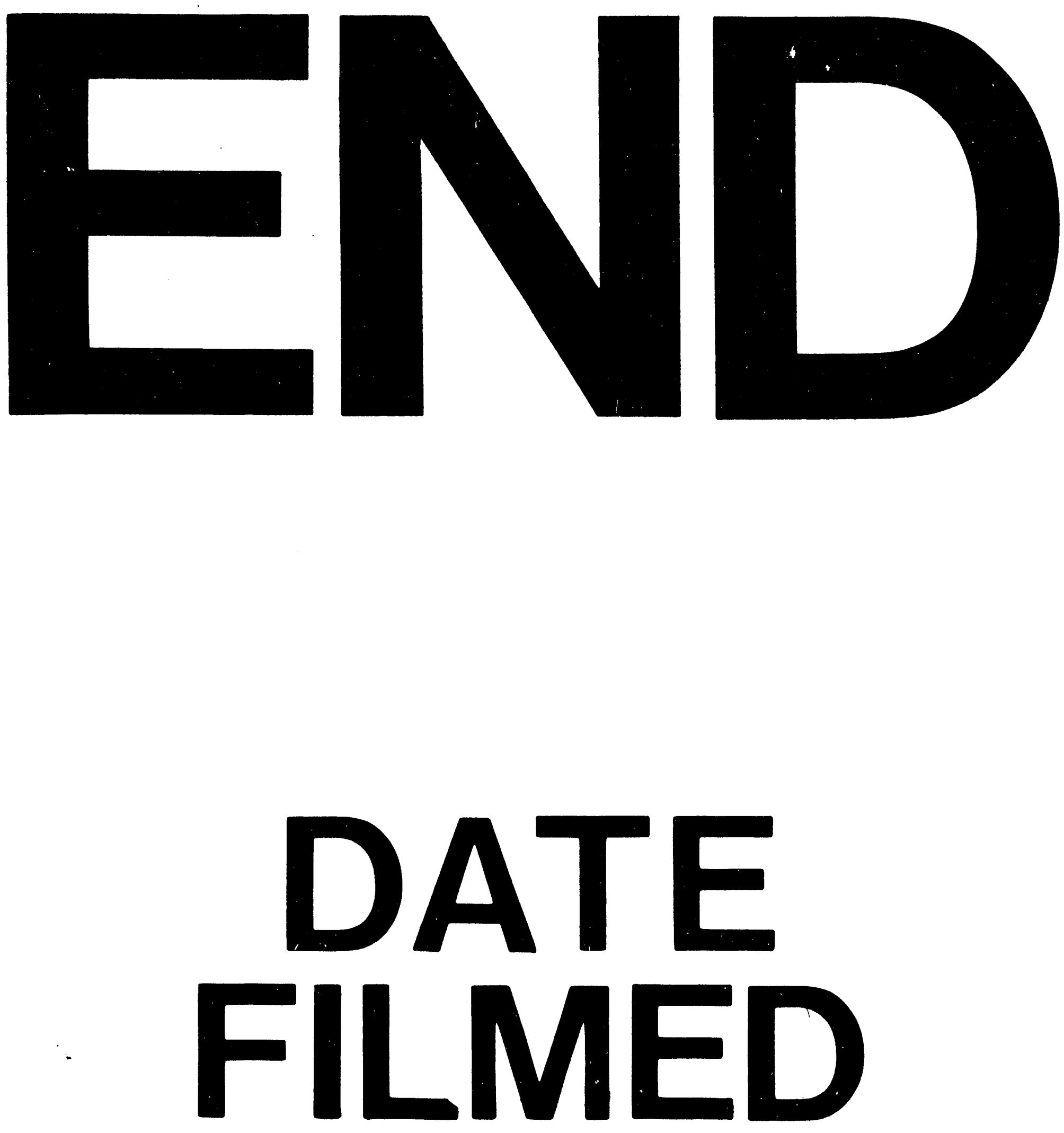

7

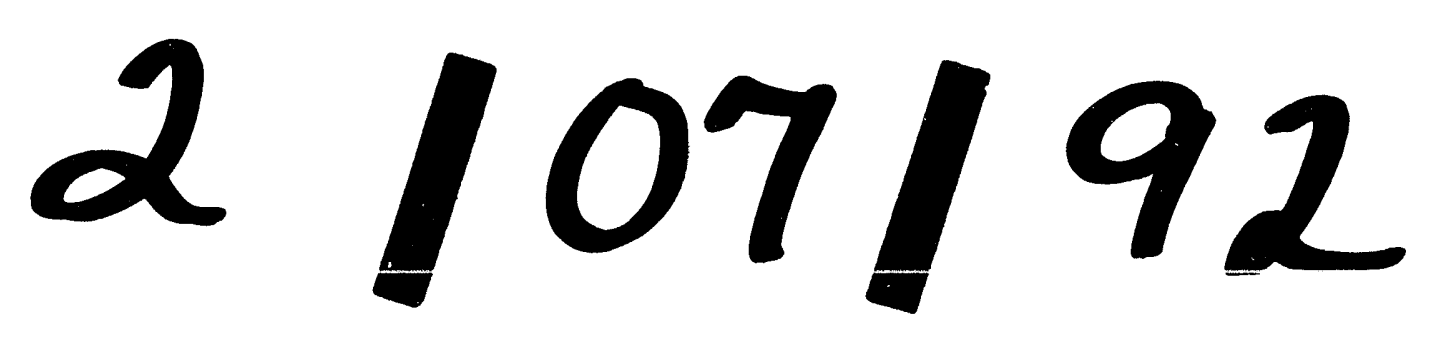


